
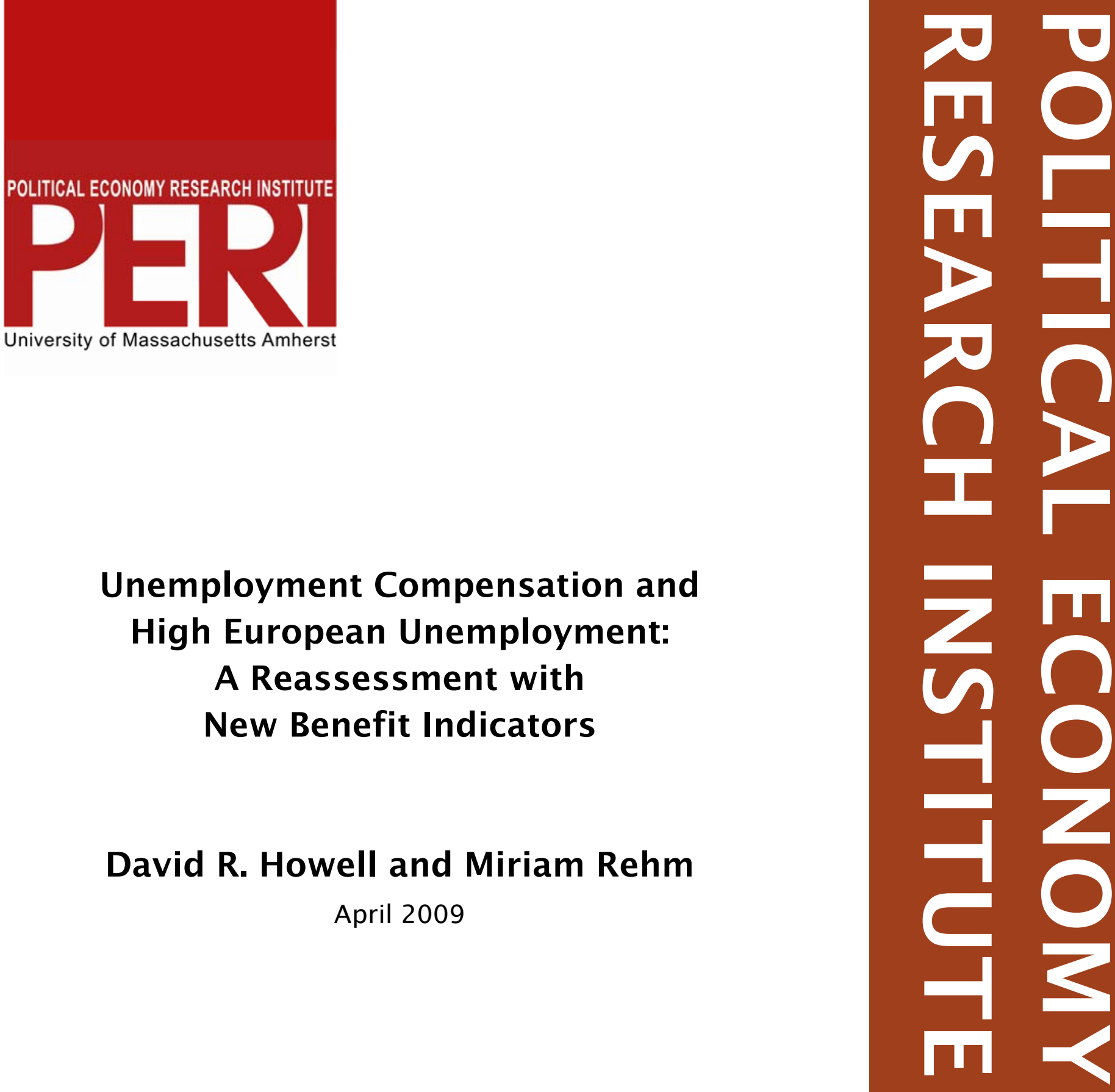

David R. Howell and Miriam Rehm

April 2009

Unemployment Compensation and High European Unemployment: A Reassessment with New Benefit Indicators

Gordon Hall

418 North Pleasant Street Amherst, MA 01002

Phone: 413.545 .6355 Fax: 413.577 .0261 peri@econs.umass.edu www.peri.umass.edu 


\title{
Unemployment Compensation and High European Unemployment: A Reassessment with New Benefit Indicators
}

\author{
David R. Howell and Miriam Rehm ${ }^{1}$
}

Generous unemployment benefits lie at the heart of the conventional explanation for persistent high unemployment. The effects of benefit generosity are more ambiguous in a broader behavioral framework in which workers get substantial disutility from unemployment controlling for income, and know that unemployment has scarring effects in the future. The micro evidence suggests modest effects of changes in generosity, but there are reasons to doubt that the impacts on national unemployment rates are consequential. The strongest evidence for the orthodox prediction comes from cross-country regressions on the OECD's gross replacement rate (GRR), but we find little support in the pattern of annual changes in the GRR and the unemployment rate for OECD countries over the last three decades. We take advantage of newly released and much improved net replacement rate indicators from the OECD, which show little correlation with either the GRRs or with unemployment and employment rates. The evidence does not offer compelling support for the view that benefit generosity is at the root of high European unemployment.

\footnotetext{
$1 \quad$ David R. Howell is a Professor at The New School (New York City) and is a Faculty Research Scholar at the New School's Schwartz Center for Economic Policy Analysis (SCEPA) (howell@newschool.edu). Miriam Rehm (rehmm151@newschool.edu) is a doctoral student in economics at The New School and a Research Assistant at SCEPA. We thank Teresa Ghilarducci and SCEPA for supporting this project, and John Schmitt, Wiemer Salverda, Ken Mayhew, Duncan Foley and two anonymous referees for comments and suggestions. We are also extremely grateful to Lyle Scruggs and the OECD’s Andrea Bassanini, David Grubb, Herwig Immervoll, and Paul Swaim for data, explanations, clarifications, comments, and patience. Thanks, above all, to Andrew Glyn.
} 


\section{INTRODUCTION}

After a decade of sharply rising unemployment across much of the developed world, the success of the U.S. in the 1990s led to widespread acceptance of the relatively unregulated "American Model” as the best-practice standard for labor market performance (OECD, 1994, 1999; IMF, 2003). The conventional wisdom has been that persistent high unemployment is explained by the rigidities imposed by protective labor market institutions, as illustrated by the performance of the "big four” high unemployment countries (France, Germany, Italy and Spain). The dramatic improvement in labor market performance shown by the "success stories” (e.g., U.K. Ireland, Denmark, the Netherlands) is attributed to the dismantling of these protective institutions (Layard et al., 2005, Introduction; Nickell et al., 2005).

While many institutional culprits are implicated, the generosity of unemployment compensation systems has ranked among the most important. Indeed, the availability of unemployment benefits has become the cornerstone of modern theories of wages and unemployment (Holmlund, 1998, p.115): the level of unemployment compensation sets the reservation wage, which determines the demand for workers; at the same time, these benefits determine work incentives and, hence, the choice to work or remain unemployed. As a result, standard theory predicts that benefits unambiguously increase unemployment spells and duration and, consequently, the aggregate unemployment rate. As Blondal and Pearson (1995, p. 136) aptly put it in this journal over a decade ago, "Helping the unemployed, so it is argued, begets more unemployed."

Recent evidence has been interpreted to strongly support this orthodox prediction. The most influential has come from a rapidly growing macroeconometric literature, in which a measure of benefit generosity, almost always a version of the OECD's gross replacement rate (GRR), is included in regression models designed to explain the pattern of unemployment across the richest twenty-odd OECD countries. The results of a similarly expanding micro literature, which have explored the effects of changes in the generosity of particular benefit programs on the duration of individual unemployment spells, are frequently cited as supporting micro evidence (Elmeskov et al., 1998; Nickell et al., 2005; OECD, 2006, chapter 3). In addition, a number of influential papers have employed simulations to show that generous unemployment compensation can explain high unemployment in European welfare states during periods of labor market turbulence (Ljungqvist and Sargent, 1998, 2003, 2005, 2007).

It has been argued that orthodox theoretical priors have strongly influenced empirical work on institutions and labor market performance, from the design of the tests and the development of the data to the interpretation of the results and the policy recommendations (Manning, 1998; Freeman, 2005; Howell, 2005, chapters 1 and 10). In contrast, this paper is framed by a skeptical stance on the likely size of the predicted employment effects of unemployment benefits. We begin by arguing that taking a fuller account of important features of real-world labor market 
behavior produces an ambiguous theoretical relationship between benefit generosity and the incidence and duration of unemployment, resulting in a variety of possible empirical predictions.

Within this broader framework, we assess the micro evidence mainly for the magnitude of the effects of program changes in benefit generosity on individual unemployment spells and durations. Since workers value jobs and have a strong distaste for unemployment even after controlling for income, there are good reasons to expect small or negligible effects. It is also important to establish, rather than to simply presume, that increasing compensated unemployment durations at the individual level translate directly into consequential changes in the aggregate unemployment rate. In addition, it should be noted that cutbacks in generosity that successfully reduce unemployment durations may have larger downward effects on labor force participation (through discouragement) than positive effects on employment rates.

Concerning the macro evidence, there has been inadequate attention paid to the quality of benefit generosity indicators and to questions of the robustness, economic importance, direction of causality, and policy implications of the regression results. The macro literature has relied almost exclusively on a single OECD-based maximum gross replacement rate (GRR), with pre-tax benefits defined for a "typical case” (a 40 year old worker with continuous employment since age 18, averaged over various household types and income levels). The GRR measure does not include social or housing assistance, which can make up a substantial proportion of non-wage income, and is measured against the average production worker wage, an increasingly inappropriate wage measure since the vast majority of wage earners in all developed countries work outside manual occupations in the manufacturing sector.

The OECD has recently published conceptually superior net replacement rates (NNRs) for each year since 2001. These are defined as net compensation as a share of net average wage income for nearly all wage earners and are calculated both with and without social assistance. In addition, the OECD has made available estimates of recipiency rates - the share of the unemployed that receive benefits - which can be interpreted as a measure of generosity of access to unemployment benefits. We make use of these new indicators for two purposes, to assess the older GRRs as measures of replacement income generosity and to explore statistical associations between these measures of generosity and various indicators of cross-country labor market performance.

We pay particular attention to the plausibility of interpreting large, highly significant positive coefficients on the OECD's GRR as showing important causal effects of program generosity on the incidence of unemployment. Reasons for skepticism include 1) the lack of support in the observed patterns of the GRR and the unemployment rate over time for each of 19 OECD countries, 2) the weak correlations we find between the older GRRs and newly developed NRRs, and 3 ) the weak and often wrong-signed simple correlations we find between various NRR indicators and standard measures of labor market performance. 
The paper is organized as follows. Section 2 reviews the orthodox theoretical prediction and contrasts it with a behavioral framework that suggests several alternative predictions. Section 3 briefly considers the recent micro literature, concluding that the evidence is broadly consistent with the orthodox prediction but that the effects are on the whole extremely modest. Our overview of the recent macro literature in Section 4 focuses on the plausibility of large effects of the GRR on the unemployment rate. Finally, Section 5 presents some new results with the OECD's new net replacement and recipiency rates. The use of the new NNRs appears to weaken the case for a central role for benefit generosity on the pattern of unemployment across countries and over time. Section 6 concludes.

\section{Theory and Predictions}

...[O]nce you admit to yourself that wage rates and employment are profoundly entwined with social status and self-esteem, you have already left the textbook treatment of the labor market behind.... A job is a source of self-respect that even moderately cushy unemployment could never be.

(Solow, 1990, pp. 10, 40).

\section{The Orthodox Prediction}

In the standard model, benefits increase unemployment on both the demand and supply sides. On the labor demand side, generous benefits may have unemployment effects through the wagesetting process, either by increasing individuals' wage claims or, where wages are determined collectively, by encouraging unions to bargain for higher wages: the availability of unemployment benefits serves as a safety net if there are employment losses. There is scant empirical support for such demand-side effects (Layard et al., 1991, p. 211; Bean, 1994, p. 594; Baccaro and Rei, 2005, p. 29). This should not be surprising, since, as noted below, in many countries substantially less than half of the unemployed actually get benefits, and among those that do, most get income for limited durations that is far below previous earnings levels.

The case against generous benefits thus rests mainly on the strength of supply-side work disincentives. Standard labor-leisure and search models predict an unambiguous correspondence between benefit generosity and unemployment, since compensation alters the trade-off between the costs and benefits of working. The mechanism is summarized by Nicholson and Needels (2006, p. 58): “The planning horizon for a newly unemployed worker is taken to be T weeks, and this worker must choose how many weeks (u) to remain unemployed.... Workers will choose a utility maximizing duration of unemployment depending on their preferences for consumption versus leisure.” A more generous benefit alters the terms of the trade-off, offering workers leisure at a lower cost in foregone consumption. As a result, the higher the replacement rate, the more likely the worker will opt for unemployment, and the longer the potential duration of benefits, the longer will be the actual spell of unemployment. Similarly, in the simple search 
model framework, workers "choose a minimum acceptable wage such that the expected gains from searching for a better offer just equal the foregone income from extending search to obtain that offer” (Addison and Blackburn, 2000, p. 23).

We suggest three possible reasons the orthodox prediction might not hold, or hold with very minor effects on the aggregate unemployment rate. First, in contrast to the standard assumption, work incentives are not limited to the size of the gap between income from employment and from benefits. Most workers seem to get substantial utility from employment and disutility from unemployment, independently of income. Since Jahoda's (1975 [1933]) seminal study on the psychological effects of unemployment, it has been widely accepted that there is a negative correlation between unemployment and both health and happiness. A recent survey by the OECD (2008, p. 207) concludes that the empirical literature finds large negative effects on reported well-being after controlling for age, education and household income, typically attributed to issues of self-esteem and social norms. ${ }^{\mathrm{i}}$ According to Andrew Clark (2009, p. 21), "analysis of European data repeats the simple message that there is a wide gulf in well-being between employment and unemployment... There is no evidence that individuals adapt to unemployment, which starts bad and stays bad.”

Second, rational workers should recognize the 'scarring effects' of unemployment spells on future income and employment, and these scarring effects are likely to be more severe the greater the duration and frequency of unemployment spells (Arulampalam et al., 2001). Scarring has been argued to arise from the corrosive effects of unemployment on skills, from the loss of within-firm and industry networks, and on the loss of non-skill related seniority and tenure benefits.

A third consideration is that most benefits systems offer income replacement at levels well below the average income, so all but the lowest wage workers receive anything close to their previous earnings levels. In addition, eligibility rules exclude many of the unemployed in most countries. As Grubb (2005, pp. 6-7) puts it:

in Western Europe contribution records of usually 6 months or more (sometimes 18 months or more) over a period of often 1-3 years (sometimes more), are required in order to qualify... workers who have voluntarily quit their previous job or have been dismissed for misconduct lose some or all of their months of UI entitlement. Benefit sanctions in the form of temporary (sometimes permanent) loss of UI entitlement are applied following refusal of suitable work, failure to participate in official labour market programmes and some other situation.

The result is that often a minority of those defined as unemployed by the official ILO definition actually receive benefits. For example, according to Atkinson and Micklewright (1991 pp. 168990), in 1988 only 26 percent of registered unemployed in the UK and 40 percent in West Germany received unemployment insurance benefits. According to tabulations from the 
European Community Household Panel, the share of the unemployed receiving benefits in 2001 ranged from 13 percent in Greece to 53 percent for the Netherlands, with Germany at 30 percent and France at 43.5 percent (Boeri and van Ours, 2008, table 11.2, p. 229). Using administrative data for all beneficiaries but the narrow ILO definition of the unemployed, the OECD's recipiency rates for 2001 are somewhat higher (e.g., 47 percent for the U.S., 59 percent for Spain, 69 percent for the U.K., 79 percent for the Netherlands, and 81 percent for France).

In sum, the conventional individual-choice theoretic framework rests on the assumption that work is unpleasant and that unemployment is not, apart from lower income. As a result, it is only the gap between unemployment compensation and employment income that determines the work decision, and the orthodox prediction follows: there is an unambiguous positive link between unemployment benefit generosity and unemployment.

We have suggested that this need not hold, or may hold only weakly, if workers get utility from employment and disutility from unemployment independently of income, or if they recognize that unemployment spells are likely to produce long-term costs in terms of future wages and employment. As Solow (1990, p. 12) put it, “The employment and job-search choices of unemployed workers, so far as they have choices, do not seem to be governed simply, or even predominantly, by any simple trade between income and the irksomeness of labor.”

Empirically, these complicating factors suggest that we should not be surprised to find modest or even negligible effects of benefit generosity on flows into unemployment, on unemployment duration, or more generally on the aggregate unemployment rate.

\section{Alternative Predictions}

An obvious alternative explanation for a positive relationship between benefit generosity and unemployment is that causation runs the other way, from unemployment to benefits: policy makers respond to constituent demands for greater generosity during times of high unemployment. Alternatively, a cut in generosity may push workers from unemployment to inactivity rather than to employment, which would lower the unemployment rate. Indeed, there is evidence that part of the decline in U.K. unemployment in the 1990s can be explained by this mechanism (Schmitt and Wadsworth, 2005).

A negative association between benefit generosity and unemployment is also possible. For example, programs that offer generous benefits but require participation in effective active labor market programs can enhance skills, improve job matches, and encourage greater risk-taking behavior by workers (Agell, 1999, 2002). These effects could, in turn, translate into greater employment and reduced unemployment. Denmark is often cited as a model for this kind of positive synergy between active labor market programs and a generous benefits system. 
A negative relationship might also result from budgetary constraints that stem from the effects of worsening labor market conditions on the size of benefit disbursements. Policy makers might be obliged to cut back on generosity during hard times, which could affect replacement rates and/or the duration of benefits. Based on an analysis of 18 countries for 1981-99, Amable et al. (2006, p. 25) conclude that "Unemployment has a significantly negative effect on replacement rates.... The consequence(s) of a high number of unemployed are high social expenses and strong budgetary pressures, which translate into the necessity of structural spending cuts.”

The literature on European unemployment hardly mentions these alternative possible links between unemployment and the generosity of unemployment compensation. Rather, the focus has been almost entirely limited to efforts to test and confirm the orthodox prediction. This empirical work has consisted of micro quasi-experimental tests and macro cross-country regression tests. We briefly assess these literatures in the next two sections.

\section{Recent Micro Evidence}

Micro studies of benefit generosity on employment outcomes have focused on the "compensated unemployed" and have attempted to determine two distinct possible effects of changes in a benefits system's generosity. The first is on the unemployment duration of benefit recipients, while the second is on post-unemployment outcomes - e.g., job quality (wage levels), labor force participation, and employment stability. Our focus is limited to the first of these - the evidence on the links between benefit generosity and compensated unemployment duration, since it has frequently been invoked in support of cross-country regression results (Elmeskov et al., 1998, p. 9; Nickell et al., 2005, p. 4; OECD 2006, Chapter 3, p. 59). ${ }^{\text {ii }}$

\section{Benefit Generosity and Unemployment Duration}

Some early studies suggested that benefit generosity had a strong positive effect on compensated unemployment duration. For example, Lancaster and Nickell (1980) concluded that "We would regard the size of the effect of benefits on unemployment duration as being now a rather firmly established parameter” (quoted by Holmlund, 1998, p. 117). A decade later, an influential study by Katz and Meyer (1990) confirmed this assessment. But surveys of the literature have reached a different conclusion. According to Atkinson and Mickelwright (1991, p. 1712), "As with the U.S. and the U.K., the evidence (from the rest of the OECD) does not suggest that the effects of benefits on transitions out of unemployment (however defined) are large or measured with precision.” At about the same time Barr (1992, cited by Hammer, 1999, p. 132) concluded that "Despite continuing controversy, the general conclusion is that though the duration of unemployment is likely to be slightly longer at higher replacement rates, the magnitude of the effect is not large.” Taking research in the 1990s into account, Holmlund (1998, p. 118) noted that the Lancaster and Nickell conclusion "was surely premature. The effect of benefits on unemployment duration is far from a firmly established parameter that is comparable in robustness to, say, estimates of the returns to schooling." 
Over the last decade, many studies have taken advantage of natural experiment-like major policy shifts, and these have tended to find more convincing evidence for a benefits effect on unemployment duration (Card and Levine, 2000 ${ }^{\text {iii }}$; Lalive and Zweimüller, 2004). Other studies have found larger effects (Roed and Zhangs, 2003; van Ours and Vodopivec, 2007; Cockx and Ries, 2004; Lalive 2008), in particular for workers more marginally attached to the labor market.

In our assessment, the recent micro evidence offers somewhat more support for positive unemployment effects than suggested by the leading1990s surveys (Atkinson and Mickelwright, 1991; Bean, 1994; and Holmlund, 1998), but the magnitude of the effects is almost always quite modest. For example, in a study of a dramatic Austrian policy shift, Lalive et al. (2004, p. 18) the assessed the effects of the joint effect of raising the duration and level of benefits for 40-49 year olds: a 33 percent increase in potential benefit duration and a 15 percent increase in the level of benefits combined to raise unemployment duration by 3-4 days. These modest impacts are consistent with the view that workers place a positive value on having a job that is independent of income.

Any assessment of the overall net benefits of a change in benefit generosity should consider the potential effects on current living standards and on post-unemployment outcomes for benefit recipients. In one important recent study, Petrongolo (2008, p. 3) found that the substantial tightening of U.K. job search requirements in 1996 "had a strong, positive and significant impact on the outflow from claimant unemployment for the individuals affected, but a negative impact on weeks worked one year later. While the reform successfully managed to move claimants off benefits, it was not successful in getting them onto new, lasting jobs” (see also Centeno, 2004; and Tatsiramos, 2006). ${ }^{\text {iv }}$

\section{Changes in Program Generosity and the Aggregate Unemployment Rate}

While a change in the benefits system that encourages longer (shorter) compensated unemployment spells will tend to produce a higher (lower) unemployment rate, this outcome is not a necessary one. In addition to encouraging workers to choose unemployment and extend its duration, generous benefits also influence the inflows into both unemployment and employment via composition, entitlement, and labor market participation effects, which complicate the connection between the availability of unemployment benefits and the aggregate unemployment rate.

If there is a large effect of benefit generosity on compensated unemployment duration, the consequence might be felt mainly in the composition rather than the level of unemployment. As Atkinson and Mickelwright (1991, p. 1710) point out, "Suppose for example that ceteris paribus we observe that persons with higher benefits exit unemployment more slowly. This does not necessarily mean that aggregate unemployment is higher since the refusal of jobs by one group 
may lead to the work being offered to others. In other words it is the composition of unemployment which is altered.”

Higher unemployment benefit generosity can also affect inflows into employment, which could limit or offset the effect of longer unemployment duration on the aggregate unemployment rate. Rather than remain jobless and ineligible for benefits, prospective benefits may induce workers to take jobs (Blondal and Pearson, 1995, pp. 137-9). This “entitlement effect” means that "for some workers, in particular those who do not qualify (or have ceased to qualify), higher benefits will make work more attractive relative to unemployment. The effect of higher benefits on the duration of unemployment is therefore, in general, ambiguous” Holmlund (1998, p. 116).

At the same time, lower replacement rates, lower duration of benefits, and tighter eligibility requirements might lower compensated unemployment duration of benefit recipients and the aggregate unemployment rate, but do so by encouraging workers to drop out of the formal labor market (see van Ours and Vodopivec, 2007; Petrongolo, 2008).

\section{Recent Macro Evidence}

Before turning to the evidence from cross-country panel regressions, we review the extensive resort to simple correlations (and scatter plots) in support of the orthodox prediction. We consider these examples in some detail both because of their prominence in the literature and to help justify our own reliance in Section V on these methods.

\section{Correlation Evidence}

Layard et al. (1991, 1994; figure 13) present a plot of a measure of the maximum duration of benefits in years (for 1985) against the long-term share of unemployment for the mid-1980s for 15 countries and remark that "all the countries where long-term unemployment has escalated have unemployment benefits of some kind that are available for a very long period, rather than running out after 6 months (as in the USA) or 14 months (as in Sweden)” (1994, p. 59). Based on this evidence, they conclude that "In countries in which benefits are indefinitely available, employment is much less likely to rebound after a major downwards shock (1991, p. 39-40).”

This assessment had a major impact on the thinking about the (negative) employment effects of benefit generosity. But it should be noted that the key indicator here is benefit duration, a measure estimated for the mid-1980s by the U.S. Department of Health and Social Services. This "first generation" measure of cross-country benefit generosity was an estimate of the number of years a representative unemployed worker was eligible for benefits. According to Nickell and Layard (1999, Table 10), the U.S. gets a score of 0.5 while Denmark gets 2.5, Spain 3.5, and France 3.75. Like six other countries, The Netherlands received a score of 4, indicating "indefinite" duration of benefits. This indicator is also relied upon by Nickell and Layard (1999). In their survey of the benefit entitlement literature, Atkinson and Micklewright (1991) single out 
this benefit duration indicator for criticism, noting that the institutional designs of the countries with "indefinite" duration scores are quite different, and these differences have substantial effects on the effective replacement rate for different groups of the unemployed population. ${ }^{\mathrm{v}}$ The OECD developed their GRR indicators in the early 1990s for the Jobs Study (OECD, 1994) to improve upon these first generation estimates.

We can compare the benefit generosity of the nine countries that get indefinite or nearly indefinite scores (3.5 to 4 years) in the Nickell and Layard (1999) survey to the OECD's average gross replacement rate tables for the 4th and 5th years of unemployment (for a single person without dependents, and as a share of the average production worker wage) in 1985: Australia, 19\%; Belgium, 33\%; Finland, 16.7\%; France, 10.7\%; Germany, 22.5\%; Ireland, 14.3\%;

Netherlands, 25\%; Spain, 0\%; and the U.K., 14.7\%. ${ }^{\text {vi }}$ Note that these rates are for a "typical case" - a 40 year old worker with 22 years of consecutive employment - and that average effective rates tend to be only about 60 percent of these levels (Grubb, 2005, p. 4). Thus, the work disincentives suggested by “indefinite duration” may mask substantial work incentives from low 4th and 5th year replacement rates.

Our second example concerns the OECD’s influential Jobs Study (OECD, 1994). Nickell and Layard (1999) cite Chapter 8 of the Jobs Study in support of their conclusion that benefit replacement rates have an important impact on unemployment. Chapter 5 of the Jobs Study argues that "increases in a more comprehensive measure of unemployment compensation has typically been followed by an increase in unemployment but usually with a considerable lag” (p. 44). For empirical support for this long-term lagged effects claim the reader is referred to Chapter 8, which proposes to "examine correlations more systematically (p. 178).”

But despite the strong formulation supporting the orthodox prediction in Chapter 5, Chapter 8's correlations are extremely weak. For three periods (1973-77, 1979-85, and 1987-93), scatter plots are presented in Chapter 8 for the change in unemployment against the six-year average ("summary") benefits level as well as against the change in the benefits measure over the previous cycle. This produces six correlation tests, which are done for a full set of 21 countries as well as for a reduced set of 14 countries. The chapter concludes that "In data for 21 countries, none of the individual correlations are statistically significant at the 5 percent level.” For the 14country data, two of the six tests produce the expected positive correlation: 1973-77 using the level of benefit entitlements measure, and 1987-93 using the change in benefits measure. A strong orthodox conclusion was thus based on a large set of insignificant correlation results.

A third example of the use of simple correlations to support a strongly orthodox conclusion can be found in a paper by Heckman (2003, p. 373) in which the author argues that poor German employment performance can be traced to what he terms a "substantial" net benefit replacement rate of 79 percent (for 1995). This conclusion is drawn from a scatter plot in which Denmark (80 
percent), the Netherlands (82 percent), Switzerland (84 percent) and Sweden (85 percent) all show even higher net replacement rate generosity than Germany. ${ }^{\text {vii }}$

Finally, the introduction to the new edition of Layard et al. (2005) devotes considerable space to a correlation exercise that relates reforms of labor market institutions since the mid-1980s to the cross-country pattern of unemployment in 2000-1 (based on Nickell, 2003). There have been numerous reforms across OECD member countries since the early 1990s (see OECD, 2006, chapter 3) resulting in an overall reduction in the generosity of benefits programs. Layard et al. (2005) argue that up to half of the cross-country variation in changes in unemployment from the mid-1980s to 2000-1 can be attributed to the balance of employment-friendly and unfriendly reforms (“ticks” and “crosses”) in just seven protective labor market institutions. According to the authors (p. xxxvii), "We can reasonably conclude that the countries which had very high unemployment in the early 1980s and still have high unemployment today simply have too few ticks and/or too many crosses."

The stated aim of Layard et al.'s (2005) analysis is to explain the persistent high unemployment of four large European countries: France, Germany, Italy, and Spain. Policy decisions affecting unemployment benefit replacement rates or benefit duration (two of the seven institutional variables) account for over half of all the employment-unfriendly reforms (18 of 37) and hardly any of employment-friendly reforms (5 of 48). The clear implication is that the failure to reduce the replacement rate and benefit duration is at the root of the simple regression result that explains half of the variation in changes in European unemployment. But it turns out that the net ticks-minus-crosses measure does not identify three of these "Big Four" countries (Glyn et al., 2005). The exception is France, which gets the same ticks-crosses score (-3) as Switzerland - a country with a 2000-1 unemployment rate of just 2.6 percent. It is also notable that according to Layard et al.’s data, despite this apparently poor policy record, neither France nor Switzerland experienced a meaningful increase in unemployment over this period: .1 and .8 percentage points respectively (2005, Table 12).

\section{Cross-Country Regression Evidence}

While simple correlation evidence has continued to play a role in the debate over the sources of high European unemployment, an increasingly sophisticated empirical literature developed in the 1990s that relied on regression techniques using panel data to identify the institutional determinants of the cross-country pattern of unemployment, in which the OECD’s gross replacement rate was ubiquitous.

It should be noted at the outset that the continued reliance on simple correlations is justified by inherent difficulties with multiple regression tests. First, most variables remain relatively poorly measured, especially over time and across countries. For example, despite numerous tests on data from 1961 onwards, standardized unemployment rate series are available for only a handful of countries for the 1960s and 1970s; there is no good measure of employment protection for the 
1960s-80s, and the OECD’s net replacement rate is available only from 2001 onward (see Howell et al., 2007). In addition, institutional configurations cannot be easily captured by regressions, and the econometrics are complicated by the very small (usually about 20) sample of quite heterogeneous countries. Given these difficulties, wide variation in results may be expected (OECD, 2006 chapter 3; Howell, 2005; Howell et al., 2007).

Baker et al. (2005) provide a detailed survey of six leading studies designed to estimate the effects of labor market institutions on unemployment using cross-country panel regression models. ${ }^{\text {viii }}$ They find that the OECD's replacement rate and duration of benefits indicators were the only measures of protective labor market institutions showing relatively consistent support for the conventional prediction in terms of direction and statistical significance. The authors conclude (Baker et al., 2005, p. 101-2) that

Only the tax and unemployment benefit duration variables are significant in all the regressions in which they appear, although two of the regressions did not include a duration measure... The unemployment benefit replacement rate is positive and significant in five of the six sets of regression results... but here again the range of the estimates is striking. The implied impact of a 10 percentage point increase in the size of the replacement rate variable ranges from a .1 percentage point rise in unemployment (Belot and van Ours 2001) to a 1.3 percentage point increase (Elmeskov et al. 1998).

As part of their reassessment of the Jobs Strategy, the OECD's Employment Outlook (OECD, 2006, chapter 3) surveyed 17 studies, concluding that "The evidence from cross-country panel regression studies substantiates concerns that generous benefits tend to raise the equilibrium level of unemployment... In a majority of these studies, the impact of benefits on unemployment is highly significant across all alternative specifications...” (p. 59). This conclusion appears to overstate the OECD's own assessment of the studies listed in Table 3.3, which shows that not a majority, but just seven studies produced estimates showing a "significant positive impact on unemployment in all cases.” Another seven studies were judged to have estimated a significant positive impact "in most but not all cases," while the remaining three found no impact.

Two recent studies have been particularly attentive to issues of robustness. First, Baccaro and Rei (2005) examined the impacts of institutions on unemployment across 18 countries for 196098. After presenting some 72 tests in 12 tables, they conclude that "Changes in employment protection, benefit replacement rates, and (the) tax wedge seem negatively associated with changes in unemployment, even though the coefficients are (mostly but not always) insignificant. The one institutional variable we find to be positively associated with changes in unemployment is the union density change variable” (p. 44). 
Among the seven studies showing positive and statistically significant effects of the GRR indicator on unemployment, perhaps the most careful and sophisticated was produced by Bassanini and Duval (2006). The preferred results of the authors are tests run on annual data from 1982-2003 for 20 countries. The Bassanini-Duval study finds "a highly significant positive relationship... across all tested specifications” for the GRR on unemployment (OECD, 2006, p. 59). The magnitude of the unemployment benefit generosity effect is quite substantial and remarkably close to the earlier Layard et al. (2005, p. xvi) conclusion that the best evidence "indicates a 1.1 percentage point rise in equilibrium unemployment for every 10 percentage point rise in the benefit replacement rate.”

These estimates imply very large perverse effects. If France is an average country, then by cutting the French replacement rate from 39 to the German 24 percent would reduce the French unemployment rate by 1.8 percentage points, or by almost half a million workers - about 20 percent of the French unemployed.

We evaluate the plausibility of the nearly identical Layard et al. (2005) and Bassanini-Duval (2006) findings of a strong positive effect of the GRR on unemployment in three ways: 1) by comparing the Bassanini-Duval decomposition of their baseline results with country-specific trends in the GRR and unemployment; 2) by simple correlation evidence for various GRR indicators and unemployment across countries; and 3) by looking for evidence of causality through both Granger tests and the same country-specific GRR and unemployment trends.

\subsection{Decompositions and Country Trends}

The Bassanini and Duval study is careful to underscore that their results refer only to the "average country" over the 1982-2003 period. The authors use their baseline results to decompose the impact of changes in policies on the change in unemployment for each of the twenty countries in the analysis (2006, figure 1.2). This exercise shows that for all five "success stories" - those countries whose policies, according to the baseline regression, produced strong declines in unemployment (Netherlands, the U.S., Denmark, the U.K., and Ireland) - success was driven mainly by changes in the tax wedge and product market regulation, and not by changes in the GRR. In only two of these, Denmark and the UK, were changes (declines) in this measure of benefit generosity associated at all with lower unemployment (less than 1 percentage point in each case).

Unemployment in Europe has been concentrated in the "big four" high unemployment countries, so it is among these that reforms in benefit generosity might be viewed to be particularly important. The Bassanini-Duval decomposition shows Italy with an extremely large contribution of the GRR to unemployment (+4 percentage points), France and Spain with modest contributions (about 1 point), and Germany with no effect. Along with Italy, the decomposition results show the largest GRR effects for Portugal ( +4 points), Switzerland (more than +2 points), and Norway (slightly under +2 points). 
To interpret the meaningfulness of these decomposition results, which underlie the strong effect found for GRR in the baseline equation, it helps to look at the magnitudes and timing of trends in the OECD's GRR and the standard unemployment rate for each country. Figure 1 shows these trends for 1971-2006 for each of 18 OECD countries (the scale of the left axis, for the unemployment rate, is set at 14 for most countries, 18 for Ireland and the Netherlands, and 25 for Spain). For some countries, we also show Scruggs’ net replacement rate.

Where available, we show both the OECD's GRR and Scruggs' NRR. The latter is calculated to mimic the (old) OECD procedures and the denominator is thus, as for the GRR, limited to the average production worker wage.

\section{Figure 1 about here}

We begin with the "big four" high unemployment countries. The graph for Italy clearly shows that its benefits system was virtually non-existent until the early 1990s, long after it experienced a large scale increase in unemployment. In addition, if anything, there has been an inverse relationship between the GRR and unemployment since the mid-1990s. A rising GRR thus could not have caused a 4 point increase in the Italian unemployment rate.

The French GRR was relatively low in international comparison in the 1970s and did not increase until 1981 (to 31 percent from 24 percent in 1979). This increase (and the increase in Scruggs' NRR) took place long after the take-off of French unemployment from 2.3 percent in 1974 to 7 percent in 1981. Both the GRR and Scruggs' NRR remained fairly unchanged throughout the 1980s and 1990s as unemployment rose from about 5\% in 1979 to almost $12 \%$ in the mid-1990s.

In the case of Spain, Figure 1 shows that the GRR crept upwards slowly from a low level as the unemployment rate exploded between 1975 and 1994. In the following years, the unemployment rate fell from 23.8 percent in 1994 to 8.5 percent in 2005 with no decline in this measure of benefit generosity. Similarly, and consistent with the Bassanini-Duval decomposition results, Germany shows no correspondence between the GRR, which has been nearly perfectly flat, and the steadily rising unemployment rate.

The decompositions suggest that in addition to Italy, Portugal, Switzerland and Norway drive the baseline GRR finding. The Portuguese GRR was extremely low through 1983, around 7 percent, and then jumps to 22 percent by 1987. This increase took place about a decade after the large increase in unemployment, and there is no apparent relationship between the GRR and unemployment for the period since the mid-1980s. As in the case of Italy, the attribution of a huge 4 percentage point effect of benefit generosity changes on Portuguese unemployment ignores the timing of these trends. 
The Swiss and Norwegian GRRs increase before unemployment rises, consistent with the orthodox prediction, but Switzerland and Norway have consistently had among the lowest unemployment rates in the OECD. It should be noted that the Swiss unemployment rate is particularly poorly measured, since until 1991 it was generated from administrative data (hence the hike in that year on the graph).

In sum, while Bassanini and Duval (2006) find a strong positive effect of the GRR on unemployment in their baseline regression, their decomposition results combined with the magnitudes and timing of the trends for the GRR and unemployment in Figure 1 do not suggest that benefit generosity has been a leading cause of rising and persistently high unemployment in most OECD countries.

\subsection{GRR - Unemployment Correlation Evidence}

Consistent with the trends in Figure 1, the scatter plot shown in Figure 2 shows no correlation between percentage point changes in the 5-year GRR and changes in unemployment rates for 20 OECD countries between 1985 to 2005. Unemployment increased by 3-5 points for Sweden, Austria and Germany, Finland and New Zealand, but all show small changes in the GRR (with declines in the GRR for Sweden, Germany and New Zealand). Spain and Ireland show declines in unemployment of about 12 points, with modest increases in the GRR. Portugal and Italy show very large increases in the GRR but declines in the unemployment rate.

\section{Figure 2 about here}

According to the OECD’s Jobs Study (1994, p. 44), “increases in a more comprehensive measure of unemployment compensation have typically been followed by an increase in unemployment but usually with a considerable lag.” The OECD then suggests that the lag can be as long as 5-10 years, and even 10-20 years (chapter 8, p. 178). The most plausible orthodox story is that increases in generosity lead to increases in unemployment with a lag of 1-10 years. If this is so, a relatively high GRR at one point should be associated with a rising unemployment rate in subsequent years, especially for the "turbulent" 1980s and 1990s (Ljungqvist and Sargent, 1998).

Figure 3 ranks the standard set of 20 countries by the summary GRR in 1981 and reports the change in the unemployment rate in percentage points between 1982 and $1991 .{ }^{\mathrm{ix}}$ No relationship is readily discernible. Among the seven most generous benefits countries, only one (Ireland) shows an increase, and it is small (0.7 percentage points). Among the top four GRR countries in 1979, all had lower unemployment in 1991 than 1982 (Germany -0.9, Belgium -4.7, the Netherlands -2.6, and Denmark -0.7). There is also no consistent pattern among the seven least generous countries (Italy, Portugal, Japan, the U.S., Switzerland, Canada and Norway). 
Similarly, Figure 4 shows changes in unemployment rates for 1992-2005, with countries ranked by the 1991 GRR. Again, the level of the GRR at the start of the period shows no obvious relationship with the changes in unemployment. Of the six countries with the most generous benefits in 1991 as measured by the GRR, five show lower unemployment in 2005 than in 1992.

\section{Figures 3 and 4 about here}

\subsection{Causality}

A plausible alternative explanation for finding a positive coefficient on a measure of benefit generosity is that it reflects the tendency for policy makers to respond to constituent demands for a stronger safety net in bad times. This "policy endogeneity" is rarely explored or even mentioned in many of the most influential macro studies. An exception is Elmeskov et al. (1998, Table A.3), who report Granger-causality results that show the direction running from higher unemployment to higher unemployment benefits for three of the countries with high levels of unemployment during this period (Belgium, France, and Italy) as well as for two countries with lower unemployment levels (the United Kingdom and the United States). Consistent with these results, DiTella and MacCulloch (2002) note that "in terms of Granger causality, it is just as likely that causality runs from unemployment to benefits as it is that causality runs the opposite way (p. 413).... The evidence tends to favor the hypothesis that long-run unemployment bolsters demands for more generous long-duration benefits” (p. 418).

The Granger tests reported in Howell et al. (2007, Table 6) are consistent with the Elmeskov et al. (1998) results, and overall show little evidence of causality running in the orthodox direction, from benefits to unemployment. Indeed, for four "success stories” (Denmark, the U.K., the Netherlands, and Ireland) as well as France, Italy and the U.S. the results clearly indicate that the predicted effect runs from unemployment to benefit generosity. Boeri and van Ours (2008, p. 244) conclude that

Estimates based on macroeconomic data in the presence of this reverse causality may also attribute to the generosity of UBs the effects of other factors (e.g., other labor market institutions) that increase the duration of unemployment... unless macroeconomic studies adopt proper methods to correct for the potential presence of policy endogeneity, it may be wiser to consider the estimates of the effects of UBs on employment and unemployment based on macroeconomic data only as upper bounds.

In contrast, Bassanini and Duval's (2009) multivariate Granger tests produce support for the orthodox prediction: causation tends to run from higher benefit generosity to higher unemployment.

Again, we can examine the trends in Figure 1 to assess the plausibility of causality running from benefit generosity to unemployment. As noted above, in most cases the GRRs remain quite 
stable as unemployment shows large fluctuations, rising through the 1980s and declining after the mid-1990s. To explain high European unemployment, it is necessary to focus on the "big four” high unemployment countries. Italy quite clearly experienced sharply rising unemployment a decade prior to the introduction of its benefits system. In the case of both Spain and France, unemployment began taking off at least five years before the GRR rose, and the unemployment rate continued to rise sharply in the 1980s and 1990s even as the GRR (and Scruggs' NRR) remained largely unchanged. Regarding France, the historical experience is well-documented: in response to political protests over deregulation in the early 1980s, "the authorities expanded social spending to help protect workers from dislocation and to undercut resistance to measures of economic liberalization” (Levy, 2000, p. 309; see also Blanchard, 2006). Despite a long upward trend in unemployment, Germany shows very stable gross and net replacement rates.

In summary, this country-specific and simple correlation evidence does not offer supporting evidence for the large effects of GRR on unemployment found by Layard et al. (2005) and Bassanini and Duval (2006). The Figure 1 trends show that the timing and magnitudes of the increases and subsequent decreases in unemployment vary significantly across these 20 countries between 1971 and 2006, while their GRRs have been, in nearly every case, remarkably stable. In the two countries with notable increases in the GRR, Portugal and Italy, these increases took place after sharp increases in unemployment. Further evidence on the relationship between benefit generosity and labor market performance is explored in the next section using OECD recipiency rates and the conceptually superior OECD net replacement rates.

\section{Evidence with New Indicators}

The OECD's gross replacement rate (GRR) became available in the mid-1990s, offering researchers interested in cross-country comparisons consistent measures of benefit generosity. The OECD has just recently made available a far superior set of net replacement rate indicators as well as a consistent set of recipiency rates. This section addresses two main questions. First, the GRR indicators, which are widely used in the literature, are assessed on how well they track the new NRR and recipiency rate indicators, used here as yardsticks for two key dimensions of benefit generosity - replacement income and duration (measured as the ratio of replacement income in, say, years 4 and 5 to year 1). And second, for simple comparisons of levels and changes, we look at how closely these new indicators are associated with various measures of employment performance across countries.

It must be emphasized that conclusions inferred from simple associations of the sort reported in this section should be treated with extreme caution. At the same time, as noted above, there is ample precedent for the use of this method to establish support for the predicted association between unemployment benefits and unemployment (Layard et al., 1991; OECD, 1994; 1999; Heckman, 2003; Layard et al., 2005). If the GRR is a good measure of income replacement 
generosity, it should show at least some association with the new NRRs in cross-country tests. Further, if the orthodox prediction is as compelling as claimed, the effects of benefit generosity on employment performance should not only show up in simple correlations with the new NRRs, but should produce better results than similar tests with the less appropriately constructed GRRs. Finally, the new NRR indicators should produce at least the right signs in simple correlations (a larger NRR should be positively associated with unemployment and negatively with employment rates).

\section{The Measurement of Benefit Generosity}

Both the GRRs and the new NRRs are calculated for what the OECD terms a 'typical case', defined as a 40 year old person working full-time with continuous employment and continuous contributions to the unemployment insurance fund since the age of 18 (OECD 2007, p. 189). This is explicitly designed as the maximum benefit the system allows, but it certainly is not a 'typical' case in the sense that it reflects the typical unemployed person in a given country.

The OECD's NRRs are a vast improvement for two reasons. First, they are calculated net of taxes (both the benefits in the numerator and the average wage in the denominator), which is a much more accurate measure of the pecuniary incentives facing workers. And second, the average wage (in the denominator) is not limited to manual workers primarily in manufacturing but also covers non-manual workers and most sectors. According to the OECD (2007), the effects of this change are substantial: the wage base increases by 38 percent for the U.K and Austria, by 29 percent for France, and by 22 percent for Switzerland and Germany, while reducing the U.S. earnings base by 12 percent (OECD 2007, Figure A-1, p. 186).

A major disadvantage of the new OECD NRR indicators is that, due to the complexity of computation and the lack of comparable historical data for average earnings, they are available only since 2001. Scruggs' (2004) NRRs are available for the period 1971 to 2003 for 18 countries (Portugal and Spain are not included), but, as briefly mentioned above, these are calculated like the GRR measure, with just production worker earnings as the base.

The meaningfulness of these measures of replacement rates depend on access to benefits. Ineligible workers are faced with a zero replacement rate. As noted above, in many of the richest OECD countries far less than half of those counted as unemployed using the ILO definition actually receive benefits. The best available measure of access to benefits is the OECD's recipiency rate $(R / U)$, which is defined as the ratio of unemployment benefit recipients (from national administrative data) to the number of unemployed (based on national labor force surveys). Published recipiency rates are available from the OECD only from 1987 to 1999. For comparisons over a longer time period, we also make use of a longer unpublished series from the $\operatorname{OECD}(\mathrm{G} \mathrm{R} / \mathrm{U}){ }^{\mathrm{x}}$ 
Because the ILO definition of unemployment (not employed for a wage for even an hour in the reference week and actively searching for work) is more restrictive than most national administrative definitions of unemployment, the fraction can be larger than 100 percent. The rule of thumb used by the OECD is that rates up to around 70\% reflect less "generous" benefits systems, while those with much higher R/U rates reflects "lax" administrative procedures. ${ }^{\mathrm{xi}}$ If a larger R/U reflects easier access to benefits, the simple orthodox framework would predict it to be correlated with a higher unemployment rate and a lower employment rate.

\section{A Comparison of Benefit Indicators}

The recent macro literature has relied on various versions of the OECD's GRR to measure benefit generosity in unemployment and employment rate tests. Table 1 shows correlations between alternative unemployment benefit generosity measures for 2003 (the most recent year for which data for each variable is available) for the standard set of 20 OECD countries. ${ }^{\text {xii }}$ The 1year GRR (column 2) is closely correlated with both the OECD's NRR (0.83) and Scruggs' NRR (S_NRR) (0.85). But the summary 5-year GRR (column 1), which is a more comprehensive measure since it takes into account duration (average replacement rates over 5 years), shows a notably lower association with the 5-year NRR (0.56). The correlation is still worse for the most comprehensive indicator of replacement income, the 5-year NRR with social assistance (NRRsa, 0.34). This suggests that, at least in recent years, the GRR has only been moderately associated with those features of national UB systems most likely to affect labor supply incentives and wage-setting behavior.

\section{Table 1 about here}

To provide a more concrete illustration, Figure 5 compares the summary 5-year GRRs and 5year NRRs for 2005. The country rankings on these two indicators are quite different. Denmark takes the top position on both, but while it has a much higher GRR than the UK and Austria, the NRRs for all three countries are nearly identical. The UK's GRR is ranked $17^{\text {th }}$ while its NRR shares $2^{\text {nd }}$ place with Austria, Belgium and Finland. Austria's GRR is the same as Italy's, but Austria’s NRR is about 10 times higher (59.1\% compared to 6.5\%).

\section{Figure 5 about here}

Table 2 shows correlations for changes over time for the very short period for which we have both GRR and NRR indicators, 2001 to 2005 (the GRR is available only for odd numbered years). The 5-year GRR and NRR indicators are fairly closely correlated, at 0.71 , but there is no correlation between this GRR and the most comprehensive measure of generosity, the NRR with social assistance (0.06). Nor is there any association between the 1-year GRR and NRR. 
These differences seem substantial enough to suggest that the OECD's GRRs and their newly developed NRRs produce quite different portraits of benefit generosity across countries, both for a given year and for changes over time.

\section{Table 2 about here}

\section{Net Benefit Generosity and Comparative Labor Market Performance}

Conventional wisdom holds that both simple correlation and regression evidence show large effects of GRR generosity on the cross-country pattern of employment performance, and most notably on the unemployment rate.

Our results offer little support for this view. Table 3 presents simple correlation results for 20 countries in 2003 between seven benefit indicators and four measures of labor market performance. The coefficient for the standard generosity indicator in the literature, the summary 5-year GRR, is just 0.12, while the conceptually superior 5-year NRR shows zero correlation. The only support for the conventional prediction is the coefficient for the 1-year NRR, and even here the association is modest (0.24). The most comprehensive measure of generosity, the 5-year NRR with social assistance, is even moderately negatively correlated (-0.35). By construction, Scruggs' net replacement rates should closely track the OECD’s 1-year NRRs, and the corresponding coefficients are indeed not very different (0.24 and 0.15).

\section{Table 3 about here}

Figure 6 illustrates the lack of correlation between the OECD's new "summary" 5-year NRR measure of benefit generosity and the unemployment rate. The U.S., with a NRR of just 5 percent, had an unemployment rate similar to or higher than Austria's, Ireland's and Denmark's, whose 5-year NRRs ranged from 60 to 68 percent. The U.S. also has higher unemployment than the Netherlands, New Zealand and Norway, despite a NRR barely more than one-tenth as high. Germany and France report the highest unemployment rates, at similar levels, but the French NRR is some 20 percentage points higher.

\section{Figure 6 about here}

These results echo those of Howell et al. (2007), which explored the correlations between longterm unemployment and a variety of different OECD net benefit indicators. They found that "there is, indeed, a relationship, but it is perverse: in 2002, more generous after-tax benefits (measured as the overall average over 60 months for two earnings levels and three family types) is associated with lower unemployment across these 20 countries” (p. 17).

Long duration of benefits is also expected to help explain high unemployment. Howell et al. (2007, Figure 3) show that higher levels of benefit duration are actually associated with lower 
unemployment in 2001 (p. 18). Following Layard et al (1991), Howell et al. (2007, Figure 4) plot long-term unemployment against the duration of benefits: "The data again fail to show the predicted positive association between benefit generosity and unemployment” (Howell et al., 2007, p. 18).

Table 3 also presents results for employment rates and separately for prime-age workers (pa). While the 5-year GRR and 5-year NRR show the predicted (but very weak) negative correlation with the employment-population ratio (column 5), the one-year replacement rates, as well as Scruggs' NRR, are (weakly) positively correlated. The most striking result is for the OECD's NRR with social assistance, which is fairly strongly positively correlated (0.46) with the employment rate, a result that is entirely inconsistent with the orthodox prediction.

As noted above, OECD gross and net replacement measures are maximum benefit levels, calculated for a 40 year old with 22 years of continuous employment. For this reason, the conventional prediction should hold more strongly for correlations between these rates and labor force performance indicators for prime age workers ${ }^{\text {xii }}$ than for overall labor force indicators. ${ }^{\text {xiv }}$ The results in Table 3 confirm this expectation. The strongest results are for the prime-age employment rate and the most comprehensive measure of benefits, the 5-year NRR with social assistance, but with reversed sign: limiting the population to prime-age workers increases the coefficient from 0.46 to 0.69 . That is, greater benefit generosity is significantly positively associated with employment rates, and the fit is substantially stronger for prime-age than for all workers.

\section{Figure 7 about here}

Overall, simple correlations between the OECD's improved net replacement rate indicators and the cross-country pattern of labor force performance in the early 2000s offer little support for the orthodox prediction. Most strikingly, the most comprehensive measure of replacement rate generosity, the 5 year NRR with social assistance, has wrongly signed and large coefficients - a higher NRR with social assistance is associated with lower unemployment (-.35) and higher employment rates (.69).

\section{Changes in Benefit Generosity and Employment Performance}

We now consider the correlations among changes in these measures of benefit generosity and changes in employment performance since the early 1980s. Three generosity measures are available for this period: the GRR, Scruggs' NRR, and the OECD's recipiency rate. Table 4 presents correlation results for all workers and separately for prime-age workers. We find no simple correlation here for changes in the GRR, but we do for Scruggs' NRR.

Furthermore, changes in the recipiency rate - the share of the unemployed receiving benefits are negatively correlated to changes in the unemployment. The recipiency rate is negatively 
correlated with unemployment (-0.46 for the total, -0.66 for prime-age) and positively correlated with the employment rate ( 0.75 for the total; 0.79 for prime-age). As mentioned above, one possible explanation for this is the ability of countries with high employment and low unemployment rates to offer benefits to most of the unemployed. But if the recipiency rate reflects generous eligibility rules and lax enforcement, these results are not consistent with the orthodox prediction that such generosity substantially undermines employment incentives.

\section{Table 4 about here}

The new OECD NRR indicators are available only since 2001. For the standard unemployment rate (column 1), Table 5 reports that only the 1-year GRR (the replacement rate) shows the expected positive correlation (0.37). In contrast, the 1-year NRR is negatively correlated (-0.17), and the summary 5-year NRR is strongly negatively correlated (-0.49). Most striking is the moderately strong positive correlation between the 5-year GRR and 5-year NRR and employment-population ratios (0.39 and 0.37 ) - countries with increasingly generous replacement rates and benefit durations appear to be associated with increasing employment rates. Again, the results are strongest, as expected, for prime age workers. But for both populations (total and prime age), the results for both unemployment and employment rates are strongly inconsistent with the orthodox prediction.

\section{Table 5 about here}

Figure 7 is constructed like Figures 3 and 4, but shows the percentage point change in unemployment for 2001-6 ranked by the OECD's 5-year NRR in 2001. As for the GRR in Figures 3and 4, there is no apparent correspondence, with low NRR (ungenerous) countries showing both declining unemployment (Italy, Japan and Canada) and rising unemployment (Sweden and Switzerland), and high NRR (generous) countries showing both rising unemployment (Netherlands, Belgium and Germany) and declining unemployment (Finland and Denmark). For many countries, movements in the unemployment rate since 2001 are inconsistent with the orthodox prediction for both the level (2001) and change (2001-6) in the 5-year NRR.

\section{Figure 7 about here}

Finally, the literature has placed much emphasis on the strictness of eligibility rules and especially the strictness in their enforcement. For example, Layard et al. (2005, p. xxviii) point out that "Denmark, which has very generous unemployment benefits, totally reformed the operation of its benefits system through the 1990s with a view to tightening the criteria for benefit receipt and the enforcement of these criteria via a comprehensive system of sanctions. The Danish Ministry of Labour is convinced that this process has played a major role in allowing Danish unemployment to fall dramatically since the early 1990s...”. 
This tightening should be revealed in the relationship between the OECD's recipiency and unemployment rates for Denmark. Figure 8 plots OECD's coverage rate with the standardized unemployment rate. The coverage rate is fairly stable over this period, between $90-100$ percent, with the exception of 1994-7, when it jumps upward just as the unemployment rate falls sharply: between 1993 and 1997 the unemployment rate dropped from 10.7 to 5.3 percent and the coverage rate rose from 90.8 to 118.4 percent. There is no evidence here that suggests that tightened access to benefits came prior to the dramatic decline in Danish unemployment in the mid-1990s.

\section{Figure 8 about here}

More generally, increasing access to benefits by the unemployed, at least as measured by the OECD's recipiency rate, is not associated with increasing unemployment over the last two decades. Figure 9 shows a plot of the change in unemployment and change in recipiency rates (in percentage points) for 1985-2004 for the 15 countries for which there is recipiency data. Of the four "success stories" included here - the UK, Spain, the Netherlands, and Ireland - all but the UK were characterized by large increases in recipiency rates. With low unemployment, Denmark's rate (91) was well above that of high-unemployment France (80). Germany’s rate was relatively high (106 in 2003-4) but was the same as Australia’s (107), and far below lowunemployment Ireland (174).

\section{Figure 9 about here}

\section{Conclusion}

This paper considers evidence for the orthodox view that access to generous unemployment benefits has played a leading role in explaining the cross-country pattern of unemployment since the early 1980s. We find that empirical support for this prediction in the literature to date is far less compelling than widely believed.

In the standard view, the presumed causal link between unemployment benefits and unemployment is predicated on the assumption that work incentives reflect the gap between income from employment and income from benefits. But this assumption may greatly overemphasize the importance of this gap for the decision to work if workers get substantial utility from employment and disutility from unemployment (given income), or if workers know that they face scarring effects of unemployment spells on future wages and employment. This broader framework would suggest that it should not be surprising to find weak and even inconsistent evidence for the orthodox prediction.

The micro evidence on the effects of benefits on the duration of compensated unemployment has become more strongly supportive of the conventional view, but the magnitude of the effects 
continue to be rather small, with the largest impacts found for workers with the least labor market attachment (as compared to prime age workers, for example, which may have important policy implications). In any case, it should be recognized that the implications of policy reforms that reduce benefit generosity in order to reduce the duration of worker unemployment spells have ambiguous implications for overall national unemployment and employment rates: these program reforms may just substitute uncompensated unemployment for those who had been compensated; they may increase discouragement and cause newly uncompensated unemployed workers to drop out of the formal labor market; or they may change only the composition of the unemployed as formerly compensated unemployed workers get jobs that would have gone to others in a less than full employment labor market.

The cross-country macro evidence is widely held to lend strong support for the orthodox account. Simple correlation evidence has frequently been cited in support of a strong benefits-tounemployment effect. We read this evidence to be quite thin, often based on rather uncritical interpretations of weak correlations with the OECD's gross replacement rate (GRR), a measure that fails to reflect key incentive-related dimensions of the compensation actually available to most workers. We show that neither a wide variety of correlation tests nor the simple pattern of country-specific time trends in the GRR and unemployment for 19 OECD countries provide much support for the orthodox prediction.

The OECD's new net replacement rates (NRRs) are much superior indicators for the purpose of testing the incentive effects of unemployment benefit generosity. Our results with these measures produce two main findings. First, they show only low or moderate association with the conventional GRR indicators; and second, the new NRR indicators show little association in either the levels or changes in unemployment and employment rates across the standard set of OECD countries. Indeed, the coefficients are often large with the wrong signs.

Much of the policy debate over the best way to reduce the incidence of unemployment has been framed by the results of cross-country correlation and regression tests, interpreted to support large cutbacks in benefit generosity. Our assessment of the evidence challenges this conventional view. In order to identify the reforms beneficial for each country, there is a need for careful country-specific analysis of the full costs and benefits of major reforms in unemployment benefit generosity. National unemployment compensation systems have been scrutinized to identify reforms that will minimize work disincentives, often with little attention paid to the positive payoffs to generous benefits, which range from effects on living standards to better job matching and improved long run employment outcomes. In order to identify the reforms beneficial for each country, there is a need for careful country-specific analysis of the full costs and benefits of major reforms in unemployment benefit generosity. As Andrew Glyn (1995, p. 1) put it in this journal over a decade ago: "In this broader context, policies have to be examined not only for their effectiveness in reducing unemployment, but also for the distribution of costs and benefits." 
See also Sullivan and von Wachter (2008), Shields and Wheatley Price (2005), Blanchflower and Oswald (2004), Clark (2003, 2009), and Di Tella et al. (2002).

ii All three of these studies cite Holmlund's survey (1998) for microeconometric evidence supportive of a strong benefit generosity-to-unemployment effect. But what Holmlund actually writes appears quite different: "Do the estimates from micro data give reliable answers to general-equilibrium questions about the effects UI on unemployment? In general, the answer is no” (p. 125). Holmlund concludes that "[t]he weight of the evidence suggests that increased benefit generosity causes longer spells of unemployment and probably higher overall unemployment as well. But there remains a considerable degree of uncertainty regarding the magnitudes of these effects” (p. 137).

iii In this study, the authors attempted to deal with policy endogeneity, which may have affected the results of Katz and Meyer (1990).

iv Other studies find little or no effect on post-unemployment job quality (Card et al., 2007; Lalive, 2008; van Ours and Vodopivec, 2008). But we are aware of no studies that show that greater benefit generosity produces worse post-unemployment labor market outcomes for benefit recipients.

v Atkinson and Mickelwright (1991) refer to the "duration of benefit" scores from Layard and Bean (1989), which are similar: all four countries receiving an "indefinite" score in the Layard data that are reproduced in Atkinson and Micklewright get the same score in Table 5 of Layard et al. (1994), which is the source for the benefits variable in the scatter plot.

vi These data were generously provided by David Grubb of the OECD.

vii It goes unmentioned that, while these levels of benefit generosity have remained stable at high levels since 1995 for these four countries, their unemployment rates have been consistently lower than Germany's. Indeed, three of the four (Sweden is the exception, but just barely) have shown lower unemployment rates than the U.S. since the late 1990s, despite a much lower U.S. net replacement rate. viii These are Nickell, 1997, Elmeskov et al., 1998; Belot and van Ours, 2001; Nickell et al. 2003; Blanchard and Wolfers, 2000; and Bertola et al. 2001.

ix The results are robust to variations in the starting and ending points.

x This series was kindly provided by David Grubb (see Carcillo and Grubb, 2006).

xi This is based on personal correspondence with David Grubb.

xii These are Australia, Austria, Belgium, Canada, Denmark, Finland, France, Germany, Italy, Ireland, Japan the Netherlands, New Zealand, Norway, Portugal, Spain, Switzerland, Sweden, the United Kingdom, and the United States.

xiii These are defined as workers aged 25 to 54 years. Data is available for most countries from 1971 until 2006 from the OECD Labor Force Statistics.

xiv The standard unemployment rate is calculated for workers aged 15 to 64 . 
Table 1: Correlation of Selected Measures of Unemployment Benefit Generosity for 20 OECD Countries, 2003*.

\begin{tabular}{|c|cc|}
\hline & GRR 5yrs & GRR 1yr \\
\hline NRR 5yrs & 0.56 & -0.07 \\
GRR 1yr & 0.59 & 1 \\
NRR 1yr & 0.46 & 0.83 \\
NRRsa 5yrs & 0.34 & 0.26 \\
S NRR & 0.36 & 0.85 \\
G R/U & 0.32 & -0.04 \\
\hline
\end{tabular}

* Countries: Australia, Austria, Belgium, Canada, Denmark, Finland, France, Germany, Ireland, Italy, Japan, Netherlands, New Zealand, Norway, Portugal, Spain, Sweden, Switzerland, U.K, U.S.;

Data: 2002 for G R/U for Canada; 2002 for S NRR for Australia, Austria, Canada, Denmark, Finland, France, Norway, Netherlands, Spain, Switzerland, and the U.S.

Notes: GRR = Gross replacement rate; NRRsa $=$ NRR incl. social assistance $\mathrm{NRR}=$ Net replacement rate rate

$\mathrm{RU}=$ Recipiency rate (unemployment benefit recipients from administrative data as a share of the unemployed as defined by labor force surveys using the ILO definition).

Source: GRRs, NRRs, NRRsa: OECD, Tax Benefit Models, available at www.oecd.org/els/social/workincentives, accessed 080815; S NRR: Scruggs, L. (2004): Welfare State Entitlements Data Set: A Comparative Institutional Analysis of Eighteen Welfare States, Version 1.1, available at http://sp.uconn.edu/ scruggs/wp.htm, accessed 080922; RU: personal communication from David Grubb (OECD);

Authors' calculations.

Table 2: Correlation of Changes in Unemployment Benefit Generosity Indicators for 20 OECD Countries, 2001 to 2005*.

\begin{tabular}{|l|rr|}
\hline & GRR 5yrs & GRR 1yr \\
\hline NRR 5yrs & 0.71 & -0.12 \\
NRR 1yr & 0.08 & 0.01 \\
NRRsa 5yrs & 0.06 & 0.03 \\
\hline
\end{tabular}

* See footnotes to Table 1.

Source: See Table 1. 
Table 3: Correlation of Unemployment Benefit and Labor Market Performance Indicators for 20 OECD Countries, 2003*

\begin{tabular}{|l|rrrrrr|}
\hline & U/LF & $\begin{array}{c}\text { U/LF } \\
\text { pa }\end{array}$ & U/pop & $\begin{array}{c}\text { U/pop } \\
\text { pa }\end{array}$ & E/pop & $\begin{array}{c}\text { E/pop } \\
\text { pa }\end{array}$ \\
\hline GRR 5yrs & 0.12 & 0.16 & 0.04 & 0.17 & -0.26 & 0.05 \\
NRR 5yrs & 0.00 & 0.03 & -0.01 & 0.08 & -0.11 & 0.24 \\
GRR 1yr & 0.17 & 0.20 & 0.20 & 0.23 & 0.05 & 0.24 \\
NRR 1yr & 0.24 & 0.31 & 0.31 & 0.38 & 0.11 & 0.36 \\
NRRsa & -0.35 & -0.28 & -0.26 & -0.20 & 0.46 & 0.69 \\
5yrs & 0.15 & 0.22 & 0.22 & 0.29 & 0.17 & 0.46 \\
S NRR & -0.04 & -0.03 & -0.08 & -0.02 & -0.28 & -0.05 \\
G R/U & & & & & & \\
\hline
\end{tabular}

* See footnotes to Table 1

Source: UB measures: See Table 1; U measures: OECD Labour Market Database, Ed. 2007 (LFS indicators by sex and age), available at: www.sourceoecd.org/database/employment, accessed 080819; Authors' calculations.

Table 4: Correlations between Changes in Benefit Generosity and Labor Market Performance Indicators, 1985 to $1999 *$.

\begin{tabular}{|l|rrrr|}
\hline & \multicolumn{1}{|c}{ ULF } & ULF pa & \multicolumn{1}{c|}{ Epop } & \multicolumn{1}{c|}{ Epop pa } \\
\hline GRR 5yr & 0.04 & 0.21 & -0.09 & -0.11 \\
SNRR & 0.34 & 0.50 & -0.24 & -0.33 \\
RU avg.* & -0.46 & -0.66 & 0.75 & 0.79 \\
\hline
\end{tabular}

* See footnotes to Table 1 ;

Due to annual fluctuations in the RU, the endpoints were averaged over 3 years (1984-6, 1997-9).

Source: See Table 3.

Table 5: Correlations between Changes in Unemployment Benefit and Labor Market Performance Indicators for 20 OECD Countries, 2001 to 2005.

\begin{tabular}{|l|rrrrrr|}
\hline & U/LF & $\begin{array}{c}\text { U/LF } \\
\text { pa }\end{array}$ & \multicolumn{1}{c}{ U/pop } & $\begin{array}{c}\text { U/pop } \\
\text { pa }\end{array}$ & E/pop & $\begin{array}{c}\text { E/pop } \\
\text { pa }\end{array}$ \\
\hline GRR 5yrs & -0.27 & -0.30 & -0.26 & -0.29 & 0.39 & 0.38 \\
NRR 5yrs & -0.49 & -0.51 & -0.50 & -0.51 & 0.37 & 0.50 \\
GRR 1yr & 0.37 & 0.35 & 0.35 & 0.34 & -0.34 & -0.33 \\
NRR 1yr & -0.17 & -0.19 & -0.15 & -0.17 & 0.14 & 0.26 \\
NRRsa & 0.03 & 0.09 & 0.03 & 0.09 & -0.02 & -0.05 \\
5yrs & & & & & & \\
\hline
\end{tabular}

*See footnotes to Table 1. Source: See Table 3. 
Figure 1: Gross Replacement Rates, Net Replacement Rates and Unemployment Rates for 19 OECD countries, 1971 to 2006*.
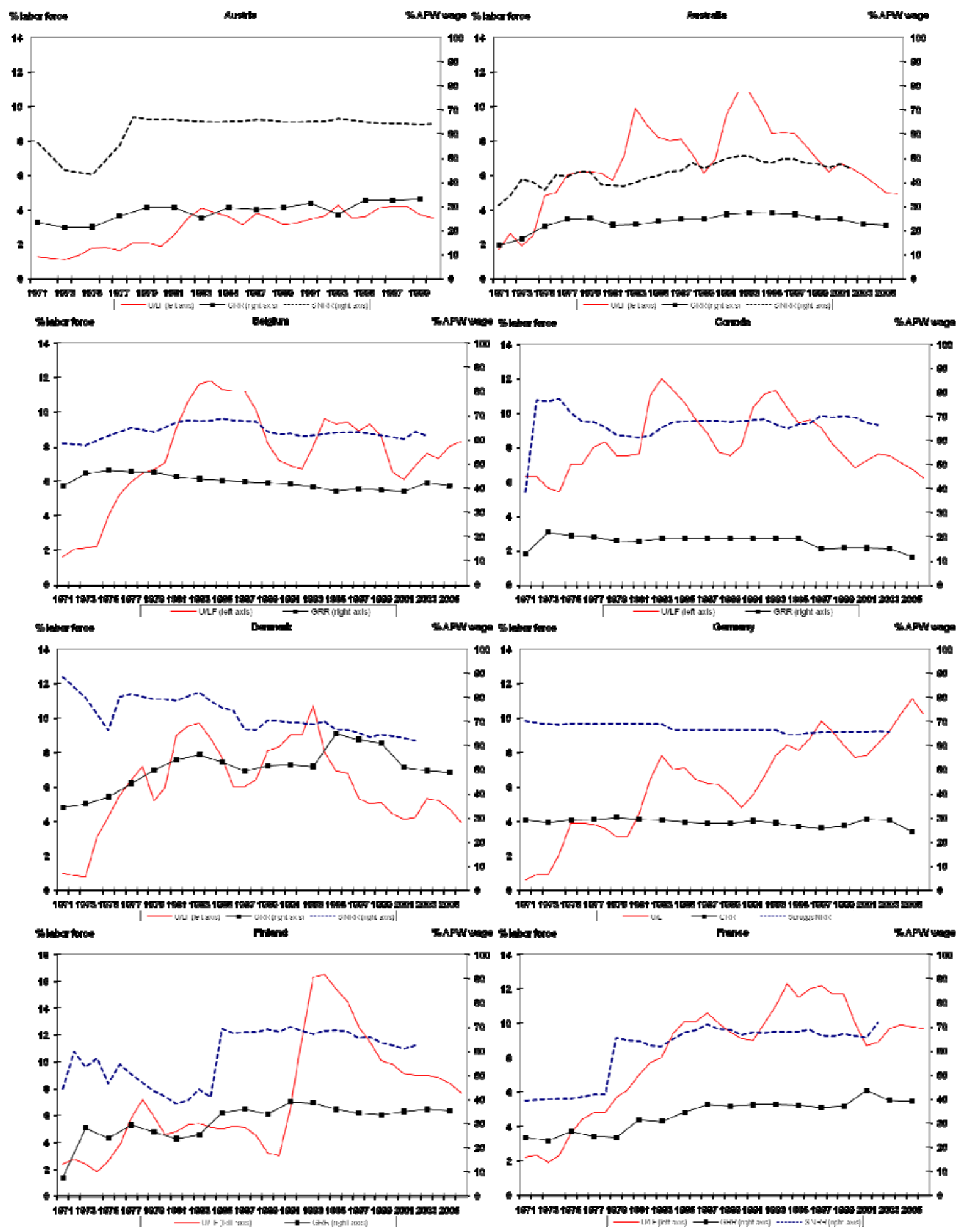

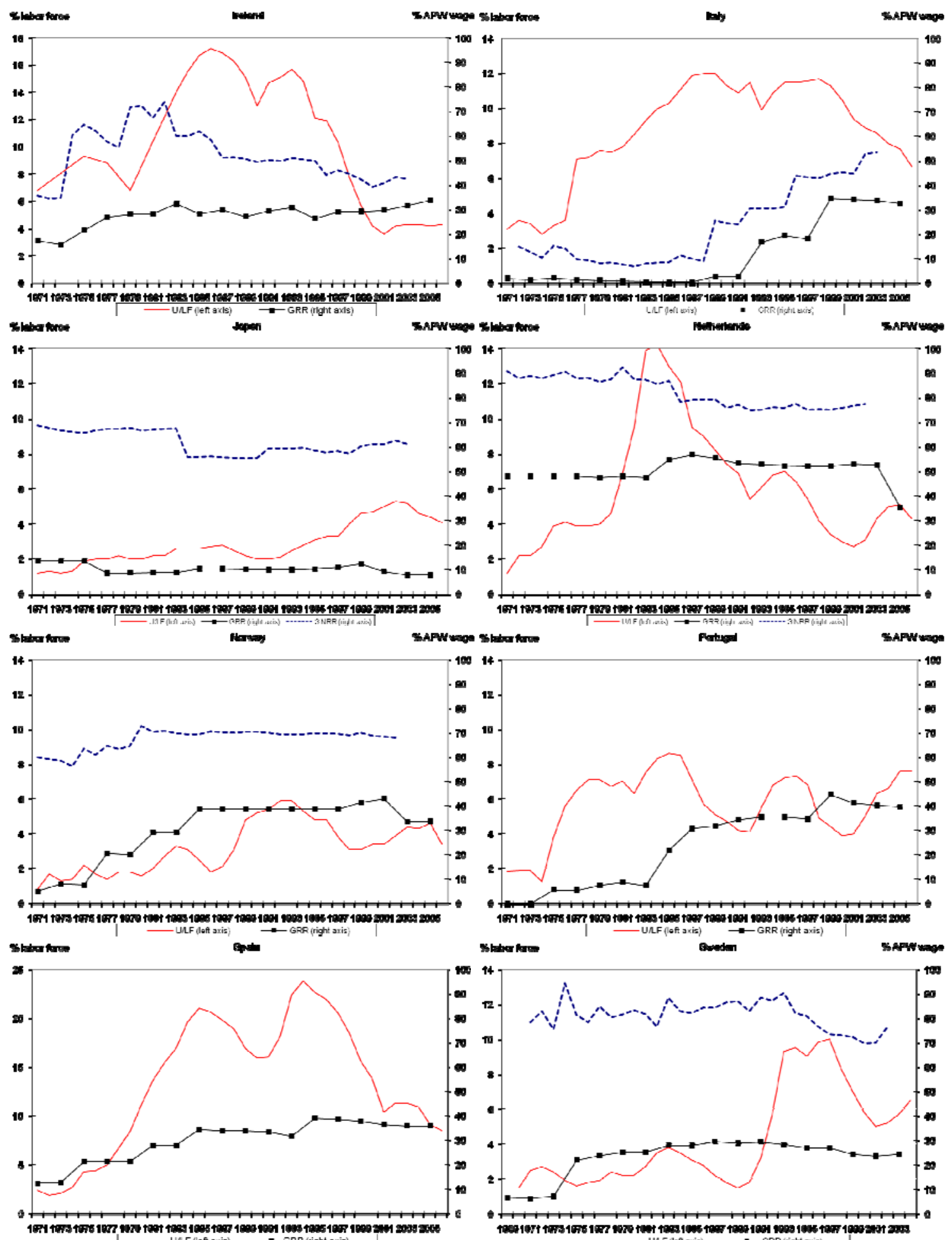


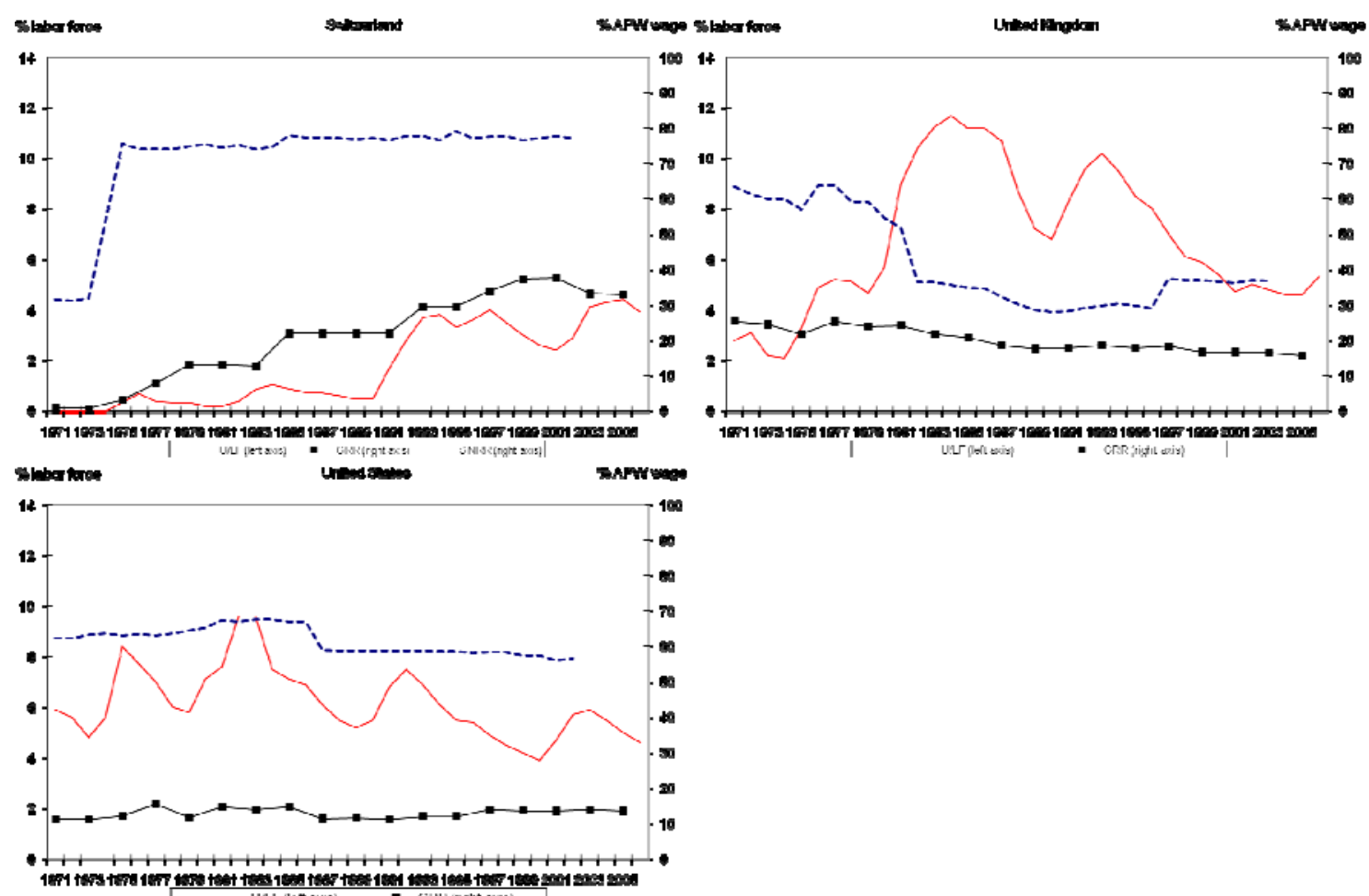

Source: OECD, Tax Benefit Models, available at www.oecd.org/els/social/workincentives, accessed 080815; Scruggs, L. (2004): Welfare State Entitlements Data Set: A Comparative Institutional Analysis of Eighteen Welfare States, Version 1.1, available at http://sp.uconn.edu/ scruggs/wp.htm, accessed 080922; See Figure 3. 
Figure 2: Change in Five-Year Gross Replacement Rates and Unemployment Rates for 20 OECD Countries, 1985 to 2005.

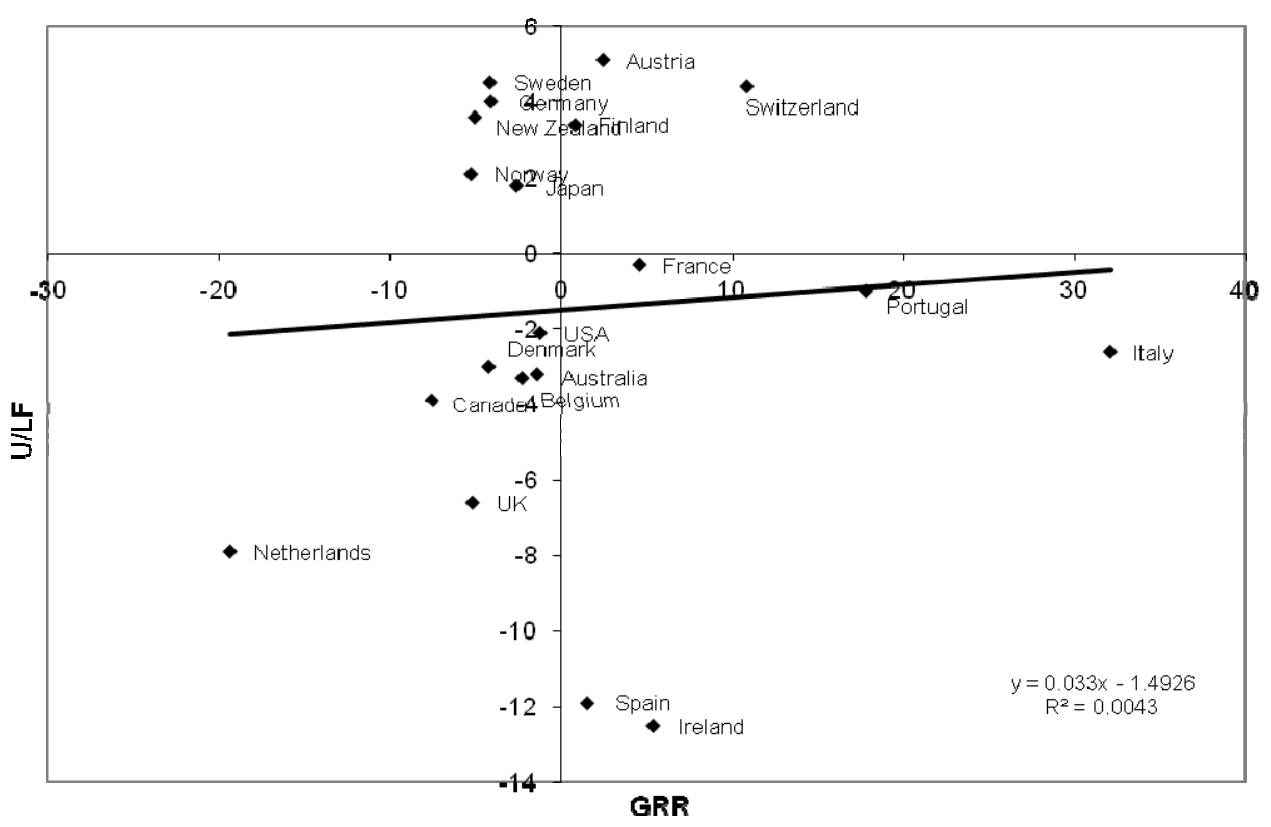

Source: OECD, Tax Benefit Models, available at www.oecd.org/els/social/workincentives, accessed 080815;

OECD Labour Market Database, Ed. 2007 (LFS indicators by sex and age), available at: www.sourceoecd.org/database/employment, accessed 080819;

Authors' calculations. 
Figure 3: Change in the Unemployment Rate (1982-91*) for 20 OECD Countries Ranked by the 1981 Five-Year Gross Replacement Rate.

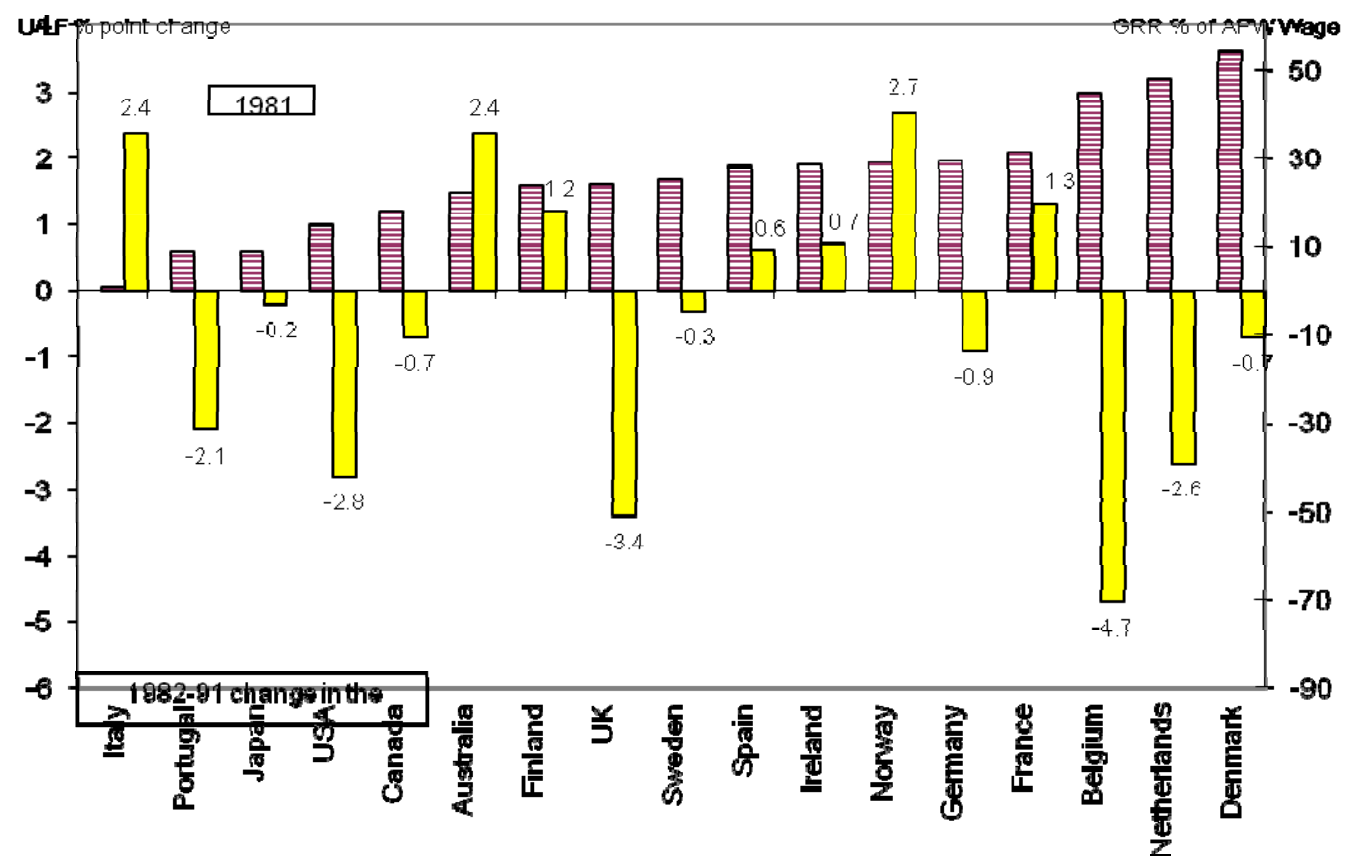

* Percentage Point Change 83-91 for Belgium, Denmark, 84-91 for U.K. Source: See Figure 2.

Figure 4: Change in the Unemployment Rate (1992-2005) for 20 OECD Countries Ranked by the 1991 Gross Replacement Rate.

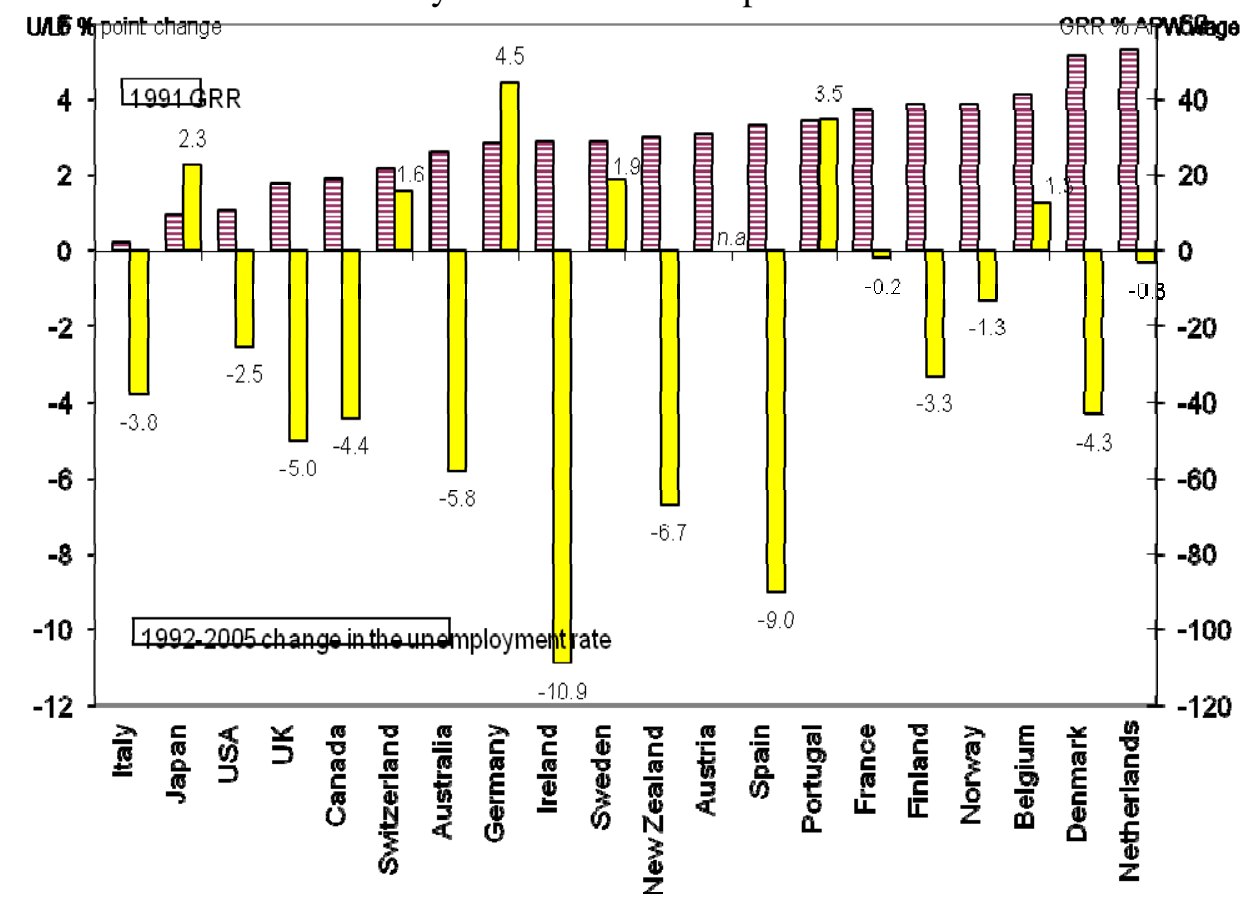

Source: See Figure 2 
Figure 5: OECD Gross Replacement Rates and Net Replacement Rates

(Including Social Assistance) for 20 Countries, 2005.

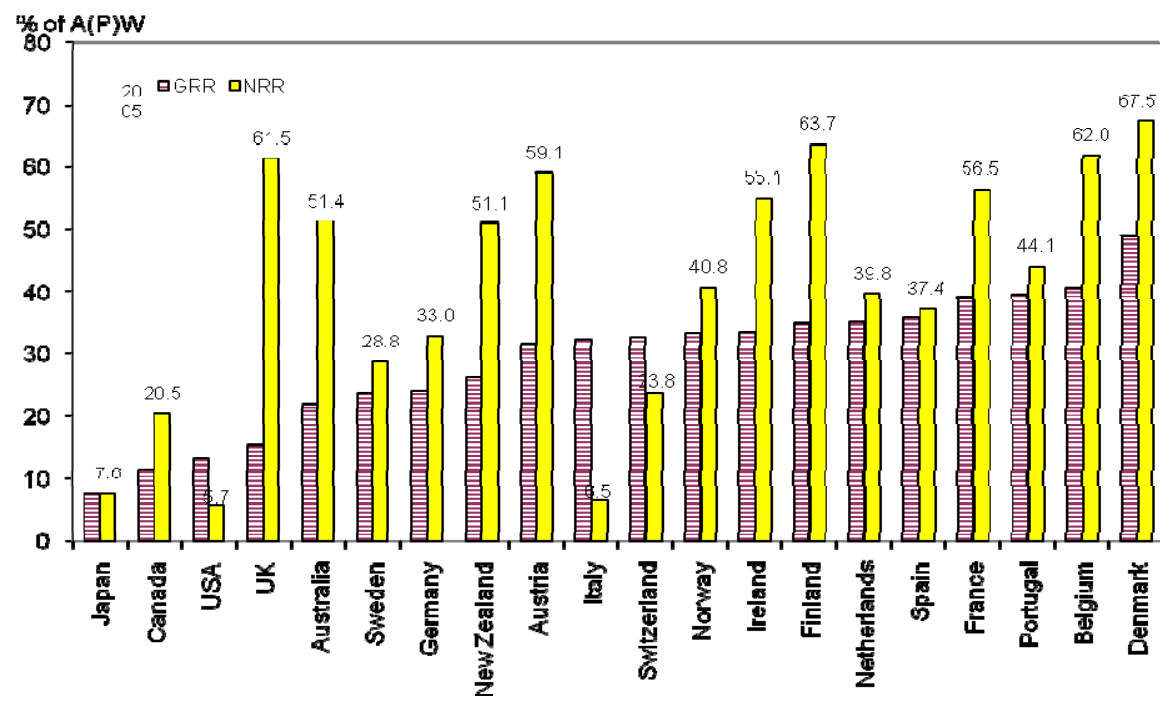

Source: OECD, Tax Benefit Models, available at www.oecd.org/els/social/workincentives, accessed 080815; Authors' calculations.

Figure 6: Five-year Net Replacement Rates and Unemployment Rates for 20 OECD Countries, 2006.

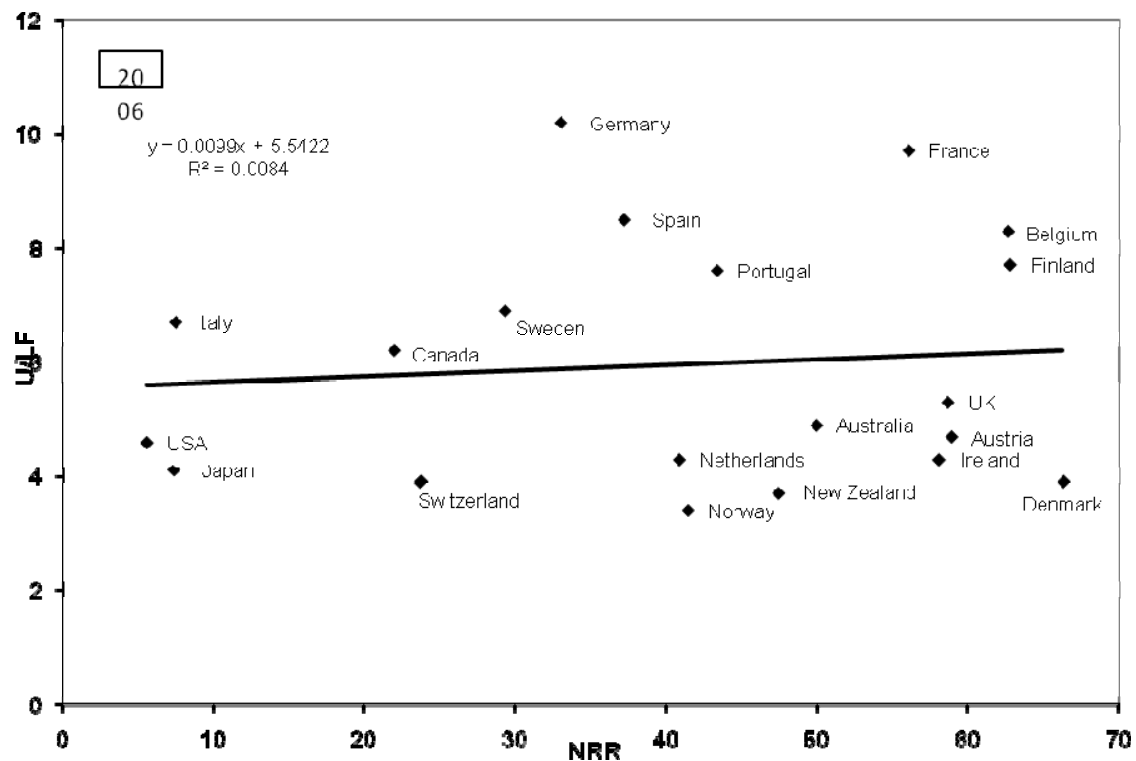

Source: OECD, Tax Benefit Models, available at www.oecd.org/els/social/workincentives, accessed 080815;

OECD Labour Market Database, Ed. 2007 (LFS indicators by sex and age), available at: www.sourceoecd.org/database/employment, accessed 080819;

Authors' calculations. 
Figure 7: Change in the Unemployment Rate (2001-2006) for 20 OECD Countries Ranked by 2001 Five-Year Net Replacement Rate.

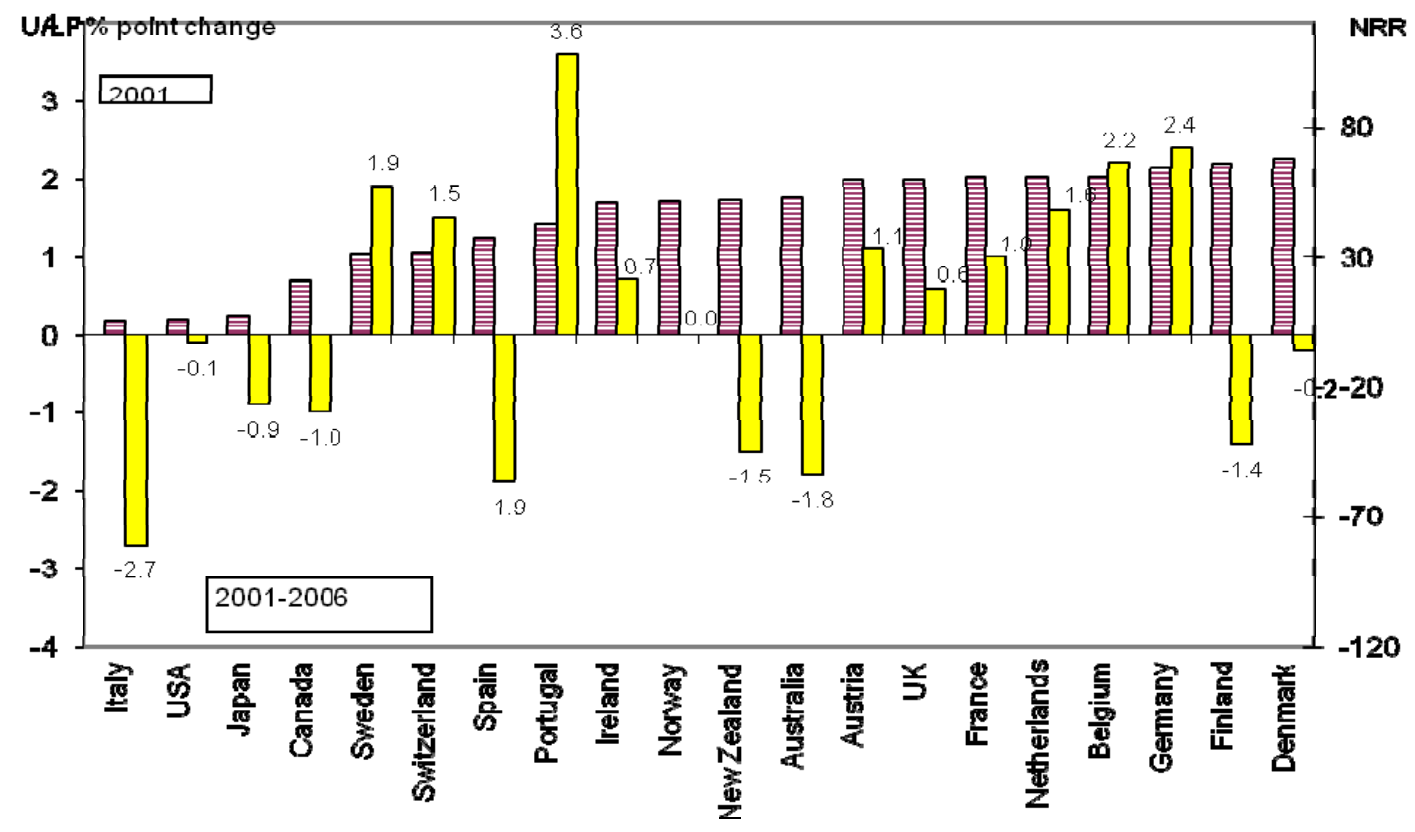

Source: See Figure 2.

Figure 8: Danish Unemployment and Recipiency Rates, 1983-2006.

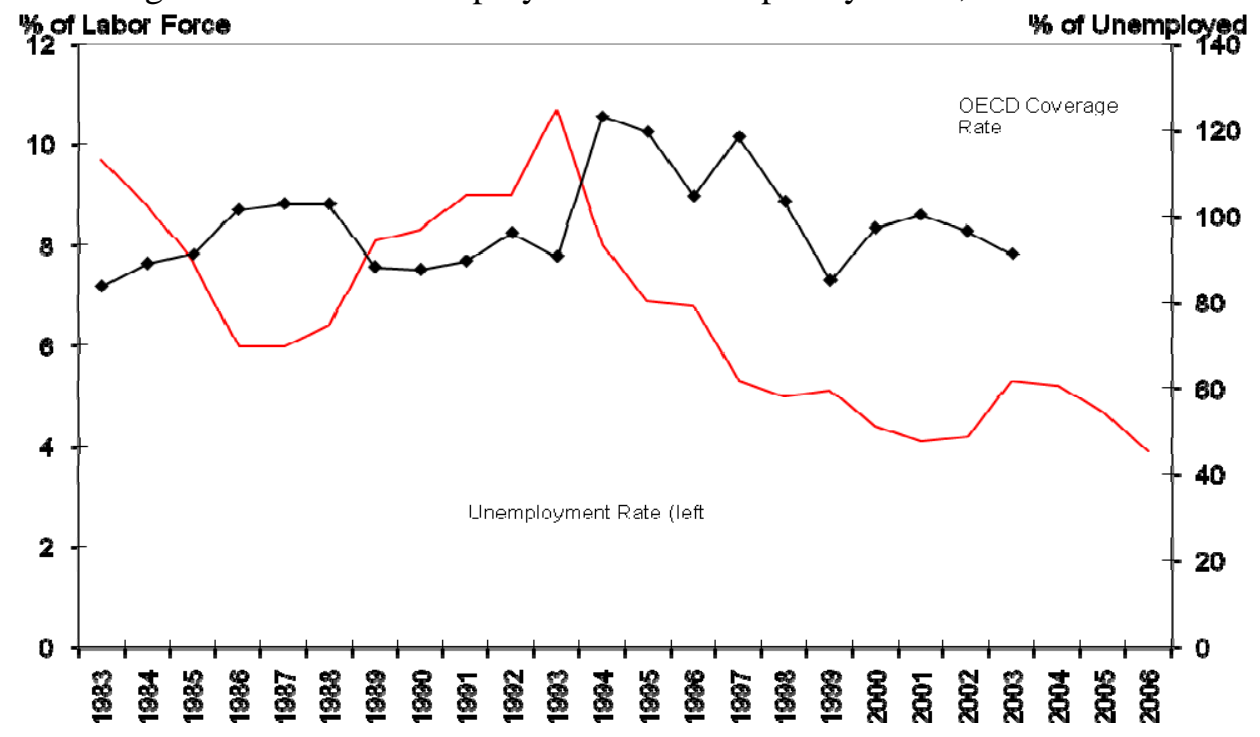

Source: OECD, Tax Benefit Models, available at www.oecd.org/els/social/workincentives, accessed 080815;

OECD Labour Market Database, Ed. 2007 (LFS indicators by sex and age), available at: www.sourceoecd.org/database/employment, accessed 080819;

Authors' calculations 
Figure 9: Changes in Unemployment and Recipiency Rates for 15 Countries, 1985-2004.

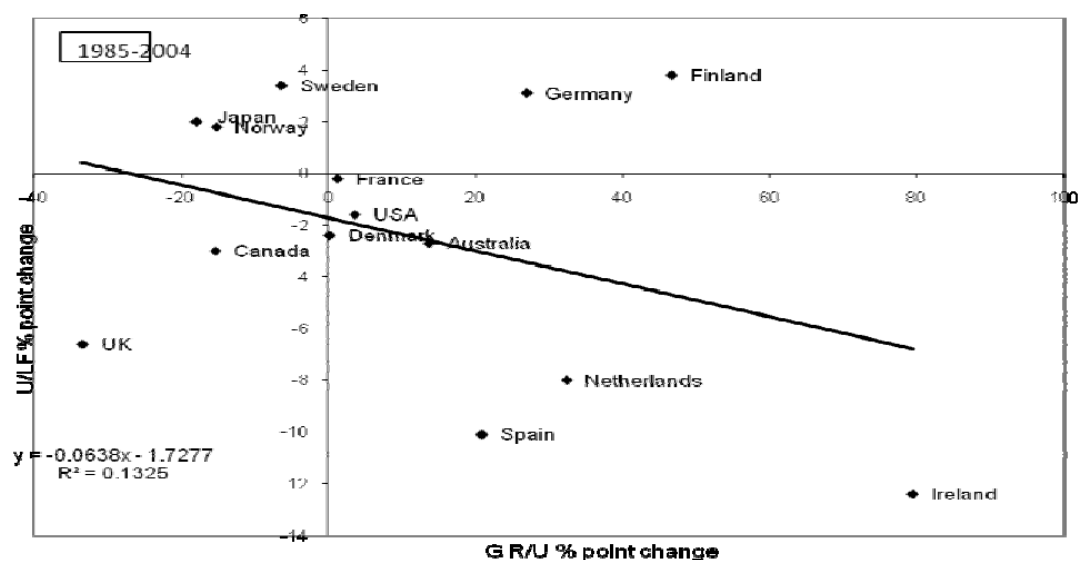

Source: OECD Labour Market Database, Ed. 2007 (LFS indicators by sex and age), available at: www.sourceoecd.org/database/employment, accessed 080819; RU: personal communication from David Grubb (OECD). 


\section{References}

Addison, J.T. and M. L. Blackburn. (2000). 'The effects of unemployment insurance on post unemployment earnings,' Labour Economics, 7(1), 21-53.

Agell, J. (1999). 'On the Benefits from Rigid Labour Markets: Norms, Market Failures, and Social Insurance,’ Economic Journal, 109, F143-F164.

Agell, J. (2002). 'On the Determinants of Labour Market Institutions: Rent Seeking vs. Social Insurance,' German Economic Review, 3, 107-135.

Amable, B., G. Donatella, and J. Schumacher. (2006). 'Welfare State Retrenchment the Partisan Effect Revisited,' Oxford Review of Economic Policy, 22, 426-444.

Arulampalam, W., Gregg, P. and M. Gregory. (2001). 'Introduction: Unemployment Scarring,' Economic Journal, 111, 475, F577-F584.

Atkinson, A. and J. Micklewright. (1991). 'Unemployment Compensation and labor market transitions: a critical review,' Journal of Economic Literature, 29, 1697-1727.

Baccaro, L. and D. Rei. (2005). 'Institutional determinants of unemployment in OECD countries: A time series cross-section analysis,' International Institute for Labour Studies Discussion Paper, DP/160/2005, International Institute for Labour Studies, Geneva.

Baker, D., A. Glyn, D. R. Howell, and J. Schmitt. (2005). 'Labor Market Institutions and Unemployment: A Critical Assessment of the Cross-Country Evidence,’ in: D. R. Howell, (ed.), Fighting Unemployment: The Limits of Free Market Orthodoxy, ch.3, Oxford, Oxford University Press.

Barr, N. (1992). 'Economic Theory and the Welfare State: A Survey and Interpretation,' Journal of Economic Literature, 30, 741-803.

Bassanini, A. and R. Duval. (2006). 'Employment Patterns in OECD Countries: reassessing the role of policies and institutions,' OECD Social, Employment and Migration Working Paper No. 35, and OECD Economics Department Working Paper No. 486, Paris.

Bassanini, A. and R. Duval. (2009). Oxford Review of Economic Policy. PLEASE ADD Bean, C. (1994). 'European Unemployment: A Survey,' Journal of Economic Literature, XXXII, 573-619.

Belot, M. and J. van Ours. (2001). 'Unemployment and labor market institutions: an empirical analysis,' Journal of the Japanese and International Economies, 15, 403-18.

Bertola, G., F. D. Blau and L. M. Kahn. (2001). Comparative Analysis of Labor Market Outcomes: Lessons for the US from International Long-Run Evidence, CEPR Discussion Paper No. 3023.

Blanchard, O.J. (2006). ‘European Unemployment: The evolution of facts and ideas,' Economic Policy, 22, 5-59.

Blanchard, O.J. and J. Wolfers. (2000). 'The Role of Shocks and Institutions in the Rise of European Unemployment: the Aggregate Evidence,' The Economic Journal, 110(March), C1C33.

Blanchflower, D. and A. Oswald. (2004). 'Well-being over time in Britain and the USA,' Journal of Public Economics, 88, 1359-1386. 
Blondal, S. and M. Pearson. (1995). 'Unemployment and Other Nonemployment Benefits,' Oxford Review of Economic Policy, 11(1), 136-169.

Boeri, T. and J. v. Ours. (2008). The Economics of Imperfect Labor Markets, Princeton, Princeton University Press.

Carcillo, S. and D. Grubb. (2006). From Inactivity to Work: The Role of Active Labour Market Policies, OECD Employment and Migration Working Papers No. 36, 1-72.

Card, D. and P. B. Levine. (2000). 'Extended benefits and the duration of UI spells: evidence from the New Jersey extended benefit program,' Journal of Public Economics, 78, 107-138. Card, D., R. Chetty, and A. Weber. (2007). 'The Spike at Benefit Exhaustion: Leaving the Unemployment System or Starting a New Job?' American Economic Review, 97(2), 113-118. Centeno, M. (2004). 'The Match Quality Gains from Unemployment Insurance,' Journal of Human Resources, XXXIX(3), 839-863.

Clark, A. (2003). 'Unemployment as a social norm: psychological evidence from panel data,' Journal of Labor Economics, 21, 323-351.

Clark, A. (2009). 'Work, Jobs and Well-Being across the Millennium', IZA Discussion Paper No. 3940 (January).

Cockx, B. L. W. and J. Ries. (2004). 'The Exhaustion of Unemployment Benefits in Belgium:

Does it Enhance the Probability of Employment?', Institute for the Study of Labor IZA

Discussion Paper No. 1177.

Di Tella, R. and R. J. MacCulloch. (2002). 'The Determination of Unemployment Benefits,' Journal of Labor Economics, 20(2), pt. 1, 404- 434.

Elmeskov, J., J. Martin, and S. Scarpetta. (1998). ‘Key Lessons for Labor Market Reforms:

Evidence from OECD Countries Experience,' Swedish Economic Policy Review, 5(2), 205-252.

Freeman, R.B. (2005). Labour Market Institutions without blinders: the debate over flexibility and labour market performance, NBER Working paper 11286 (April).

Glyn, A. (1995). 'The Assessment: Inequality and Unemployment,' Oxford Review of Economic Policy, 11(1), 1-25.

Glyn, A., D. R. Howell and J. Schmitt. (2006). 'Labor Market Reforms: The Evidence Does Not Tell the Orthodox Tale,' Challenge, 49(2), 5-22.

Grubb, D. (2005). 'Trends in Unemployment Insurance, Related Benefits and Active Labour Market Policies in Europe,' Paper prepared for the International Seminar on Employment/Unemployment Insurance celebrating the $10^{\text {th }}$ anniversary of Employment insurance in Korea $\left(7^{\text {th }}\right.$ and $8^{\text {th }}$ July 2005).

Hammer, T. (1999). 'The Influence of Different Compensation Levels of Unemployment Benefits on Job Chances Among Unemployed Youth: A Comparative Study of the Nordic Countries,' Acta Sociologica, 42, 123-34.

Heckman, James J. 2003. Flexibility and Job Creation: Lessons from Germany. In Knowledge, Information, and Expectations in Modern Macroeconomics: In Honor of Edmund S. Phelps, ed. Philippe Aghion, Roman Frydman, Joseph Stiglitz, and Michael Woodford, 357-93 (Princeton: Princeton University Press). 
Holmlund, B. (1998). 'Unemployment Insurance in Theory and Practice', Scandinavian Journal of Economics, 100(1), 143-145.

Howell, D. R. (ed.) (2005). Fighting Unemployment: The Limits of Free Market Orthodoxy. Oxford, Oxford University Press.

Howell, D. R., D. Baker, A. Glyn and J. Schmitt. (2007). 'Are Protective Labor Market Institutions at the Root of Unemployment? A Critical Review of the Evidence,' Capitalism and Society, 2(1), 1-71.

International Monetary Fund (IMF). (2003). Unemployment and Labor Market Institutions: Why Reforms Pay Off. in: IMF. World Economic Outlook. ch.VI, Washington, DC, IMF.

Jahoda, M. , P. F. Lazarsfeld and H. Zeisel. (1975 [1933]). Die Arbeitslosen von Marienthal. Ein soziographischer Versuch über die Wirkungen langandauernder Arbeitslosigkeit. Frankfurt a.M., Suhrkamp.

Katz, L. F. and B. D. Meyer. (1990). 'The Impact of the Potential Duration of Unemployment Benefits on the Duration of Unemployment', Journal of Public Economics, 41, 45-72

Kuhn, A., R. Lalive, and J. Zweimüller. (2004). 'Does Unemployment Make You Sick?', Paper presented to the IZA conference, University of Bonn, October 24-25.

Lancaster, T. and Steven Nickell. 1980. "The Analysis of Re-employment Probabilities for the Unemployed,” Journal of the Royal Statistical Society A 143, pp. 141-65.

Lalive, R. (2007). 'Unemployment Benefits, Unemployment Duration, and Post-Unemployment Jobs: A Regression Discontinuity Approach.’ American Economic Review, 97(2), 108-112.

Lalive, R. and J. Zweimüller. (2004). 'Benefit entitlement and unemployment duration: The role of policy endogeneity’, Journal of Public Economics, 88, 2587-2616.

Layard, R. and C. Bean. (1989). 'Why does unemployment persist?’ Scandinavian Journal of Economics, 91(2), 371-396.

Layard, R., S. Nickell and R. Jackman. (1991). Unemployment: Macroeconomic Performance and the Labour Market, Oxford, Oxford University Press.

Layard, R., S. Nickell and R. Jackman. (1994). The Unemployment Crisis, Oxford, Oxford University Press.

Layard, R., S. Nickell and R. Jackman. (2005). Unemployment: Macroeconomic Performance and the Labour Market, $2^{\text {nd }}$ edition, Oxford, Oxford University Press.

Levy, J. D. (2000). France: Directing Adjustment?, in: F. W. Scharpf and V. A. Schmidt (eds). Welfare and Work in the Open Economy: Diverse Responses to Common Challenges, vol. II, 308-350. Oxford, Oxford University Press.

Ljungqvist, L. and T. J. Sargent. (1998). 'The European Unemployment Dilemma', Journal of Political Economy, 106(3), 514-550.

Ljungqvist, L. and T. J. Sargent. (2003). 'European Unemployment and Turbulence Revisited in a Matching Model,’ mimeo (September 29).

Ljungqvist, L. and T. J. Sargent. (2005). 'Jobs and Unemployment in Macroeconomic Theory: A Turbulence Laboratory,' Centre for Economic Policy Research (CEPR), Discussion Paper No. 5340 . 
Ljungqvist, L. and T. J. Sargent. (2007). ‘How Sweden's Unemployment became more like Europe's,' Prepared for NBER-SNSS conference on reforming the Swedish welfare state. Manning, Alan. 1998. "Comment on B. Holmlund, 'Unemployment Insurance in Theory and Practice’”. Scandinavian Journal of Economics 100 (1), pp 143-45.

Nicholson, W. and K. Needels. (2006). 'Unemployment Insurance: Strengthening the Relationship between Theory and Policy,' Journal of Economic Literature, 20(3), Summer, 4770.

Nickell, S. (1997). 'Unemployment and Labor Market Rigidities: Europe versus North America', Journal of Economic Perspectives, 11(3), 55-74.

Nickell, S. (2003). 'Labour Market Institutions and Unemployment in OECD Countries,' CESifo DICE Report, February.

Nickell, S. and R. Layard. (1999). Labor Market Institutions and Economic Performance. in O. Ashenfelter and D. Card (eds), Handbook of Labor Economics. Volume 3, Amsterdam, Elsevier. Nickell, S., L. Nunziata and W. Ochel. (2005). 'Unemployment in the OECD since the 1960s. What do We Know?', The Economic Journal, 115(500), 1-27.

Nickell, S., L. Nunziata, W. Ochel and G. Quintini. (2003). The Beveridge Curve, Unemployment, and Wages in the OECD from the 1960s to the 1990s. in: P. Aghion, R. Frydman, J. Stiglitz, and M. Woodford (eds), Knowledge, Information, and Expectations in Modern Macroeconomics: In Honor of Edmund S. Phelps, 357-393. Princeton, Princeton University Press.

OECD (1994). OECD Jobs Study, Paris, OECD.

OECD (1999). Implementing the OECD Jobs Strategy: Assessing Performance and Policy, Paris, OECD.

OECD (2004b). Benefits and Wages, Paris, OECD.

OECD (2006). OECD Employment Outlook, Paris, OECD.

OECD (2007). OECD Employment Outlook, Paris, OECD.

OECD (2008). OECD Employment Outlook, Paris, OECD.

Pallage, S., L. Scruggs and C. Zimmermann. (2009). 'Measuring Unemployment Insurance Generosity,’ IZA Discussion Paper No. 3868, December.

Petrongolo, B. (2008). 'The Long-Term Effects of Job Search Requirements: Evidence from the UK JSA Reform,' IZA Discussion Paper No. 3856, November.

Schmitt, J. and J. Wadsworth. (2005). 'Is the OECD Jobs Strategy behind U.S. and British Employment and Unemployment Success in the 1990s?' in: D. R. Howell, (ed.), Fighting Unemployment: The Limits of Free Market Orthodoxy, ch.3, Oxford, Oxford University Press. Roed, K. and T. Zhang. 2003. "Does Unemployment Compensation Affect Unemployment Duration?”, Economic Journal 113, pp. 190-206.

Scruggs, L. (2004). Welfare State Entitlements Data Set: A Comparative Institutional Analysis of Eighteen Welfare States, Version 1.1. (http://sp.uconn.edu/ scruggs/wp.htm, accessed 080922).

Scruggs, L. (2004): Welfare Entitlements Dataset Codebook, available at http://sp.uconn.edu/ scruggs/wp.htm, accessed 080922. 
Shields, M. A. and S. Weatley Price. (2005). 'Exploring the economic and social determinants of psychological well-being and perceived social support in England,' Journal of the Royal Statistical Society, 168(3), 513-537.

Solow, R. (1990). The Labor Market as a Social Institution. Cambridge (Mass.), Blackwell. Sullivan, D. and T. von Wachter. (2007). Mortality, Mass Layoffs and Career Outcomes: An Analysis Using Administrative Data, NBER Working Paper No. W13626.

Tatsiramos, K. (2006). 'Unemployment Insurance in Europe: unemployment Duration and Subsequent Employment Stability’, IZA Discussion Paper No. 2280.

van Ours, Jan C. and Milan Vodopivec (2008) 'Does reducing unemployment insurance generosity reduce job match quality?’ Journal of Public Economics, 92, 684 - 695. 